\title{
Bio-Electro-Fenton process for the degradation of Non-Steroidal Anti-Inflammatory Drugs in wastewater
}

Nadais , Helena; Li, Xiaohu; Alves , Nadine; Couras , Cátia; Andersen, Henrik Rasmus; Angelidaki, Irini; Zhang, Yifeng

\section{Published in:}

Chemical Engineering Journal

Link to article, DOI:

10.1016/j.cej.2018.01.014

Publication date:

2018

Document Version

Peer reviewed version

Link back to DTU Orbit

Citation (APA):

Nadais , H., Li, X., Alves , N., Couras , C., Andersen, H. R., Angelidaki, I., \& Zhang, Y. (2018). Bio-ElectroFenton process for the degradation of Non-Steroidal Anti-Inflammatory Drugs in wastewater. Chemical Engineering Journal, 338, 401-410. https://doi.org/10.1016/j.cej.2018.01.014

\section{General rights}

Copyright and moral rights for the publications made accessible in the public portal are retained by the authors and/or other copyright owners and it is a condition of accessing publications that users recognise and abide by the legal requirements associated with these rights.

- Users may download and print one copy of any publication from the public portal for the purpose of private study or research.

- You may not further distribute the material or use it for any profit-making activity or commercial gain

- You may freely distribute the URL identifying the publication in the public portal 


\section{Accepted Manuscript}

Bio-Electro-Fenton process for the degradation of Non-Steroidal Anti-Inflammatory Drugs in wastewater

Nadais Helena, Li Xiaohu, Alves Nadine, Couras Cátia, Andersen Henrik Rasmus, Angelidaki Irini, Zhang Yifeng

PII: S1385-8947(18)30014-7

DOI: https://doi.org/10.1016/j.cej.2018.01.014

Reference: CEJ 18334

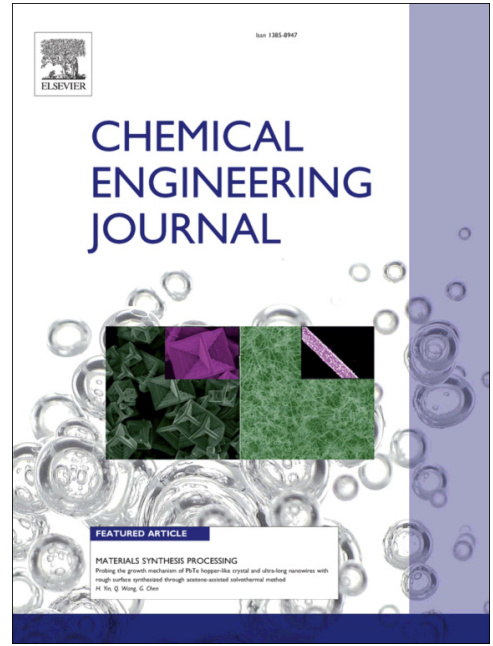

To appear in:

Chemical Engineering Journal

Received Date:

14 September 2017

Revised Date:

10 December 2017

Accepted Date:

2 January 2018

Please cite this article as: N. Helena, L. Xiaohu, A. Nadine, C. Cátia, A. Henrik Rasmus, A. Irini, Z. Yifeng, BioElectro-Fenton process for the degradation of Non-Steroidal Anti-Inflammatory Drugs in wastewater, Chemical Engineering Journal (2018), doi: https://doi.org/10.1016/j.cej.2018.01.014

This is a PDF file of an unedited manuscript that has been accepted for publication. As a service to our customers we are providing this early version of the manuscript. The manuscript will undergo copyediting, typesetting, and review of the resulting proof before it is published in its final form. Please note that during the production process errors may be discovered which could affect the content, and all legal disclaimers that apply to the journal pertain. 


\section{Bio-Electro-Fenton process for the degradation of Non-Steroidal Anti- Inflammatory Drugs in wastewater}

Nadais Helena ${ }^{\text {a)* }}$, Li Xiaohu ${ }^{\text {b) }}$, Alves Nadine ${ }^{\text {c) }}$, Couras Cátia ${ }^{\text {a) }}$, Andersen Henrik Rasmus b), Angelidaki Irini ${ }^{\text {b) }}$, Zhang Yifeng ${ }^{\text {b)* }}$

a) Centre for Environment and Marine Studies (CESAM) and Environmental and Planning Department, University of Aveiro, Campus de Santiago, 3810-193 Aveiro, Portugal

b) Department of Environmental Engineering, Building 115, Technical University of Denmark, DK2800 Lyngby, Denmark

c) Environmental and Planning Department, University of Aveiro, Campus de Santiago, 3810-193 Aveiro, Portugal

*Corresponding author, Tel.: +351 234370200; nadais@ua.pt (Helena Nadais) Tel.: +45 45251410; yifz@env.dtu.dk (Yifeng Zhang).

E-mail addresses: nadais@ua.pt (Helena Nadais), yifz@env.dtu.dk (Yifeng Zhang) 


\section{Abstract}

Non-Steroidal Anti-Inflammatory Drugs (NSAIDs) are ubiquitous municipal wastewater pollutants of which several are resistant to degradation in conventional wastewater treatment, and represent a major environmental health concern worldwide. An alternative treatment, the bio-electro-Fenton process, has received increasing attention in past years. In this process the strong oxidant ${ }^{\circ} \mathrm{HO}$ is formed using the electrons derived from bacterial oxidation of organic substrate. In this work, a laboratory scale microbial electrolysis cell based bio-electro-Fenton process was developed for the treatment of four different NSAIDs. The system was demonstrated to remove low concentration NSAIDs from water and wastewater and all tested parameters (cathode $\mathrm{pH}$, cathode air-flow, cathode $\mathrm{Fe}^{2+}$ concentration, applied voltage, NSAIDs concentration and reaction time) were found to affect the apparent first order rate constant and removal efficiency for NSAIDs. Optimum parameter values were found to be $\mathrm{pH}=2, \mathrm{Fe}^{+2}=7.5 \mathrm{mM}$, air-flow $=8 \mathrm{~mL} \mathrm{~min}^{-1}$, applied voltage $=0.3 \mathrm{~V}$; the apparent rate constant was higher for higher NSAIDs initial concentration. For reaction times of 5 hours removal efficiencies were 59\%-61\% for Ketoprofen, $87 \%-97 \%$ for Diclofenac, $80 \%-86 \%$ for Ibuprofen and $75 \%-81 \%$ for Naproxen. Prolonged reaction times lead to substantial increase in removal efficiencies for Ketoprofen and Naproxen. Finally results obtained with real wastewater show lower removal rate constants than with distilled water matrices suggesting interference from wastewater components in the NSAIDs oxidation process. The results offer insight into future developments of an efficient platform for wastewater treatment technology targeting micropollutants.

\section{Abbreviations}

AOP Advanced Oxidation Processes 
BES Bio-Electrochemical System

COD Chemical Oxygen Demand

DO Dissolved Oxygen

EAOP Electro-Chemical Advanced Oxidation Processes

E-Fenton Electro-Fenton Process

MEC Microbial Electrolytic Cells

MFC Microbial Fuel Cell

NSAIDs Non-Steroidal Anti-Inflammatory Drugs

PPCPs Pharmaceuticals and Personal Care Products

PTFE Polytetrafluoroethylene

RVC Reticulated Vitreous Carbon

SD Standard Error

\section{INTRODUCTION}

Pharmaceuticals and personal care products (PPCPs) are environmental pollutants causing concern due to their potential negative effects on aquatic species [1-4] and terrestrial media [5]. For instance, the group of Nonsteroidal Anti-Inflamatory Drugs (NSAIDs) such as diclofenac, ibuprofen, ketoprofen and naproxen are known to be used as anti-inflammatory and pain killers. They have been detected in varying concentrations in the effluents from sewage treatment plants and in surface and ground waters [6,7]. Environmental hazard assessment showed that these pharmaceuticals pose high potential danger to the environment and high risk for aquatic organisms [8-11]. Several studies have demonstrated that these pollutants cannot be fully removed in Wastewater Treatment Plants [4,6,12-18]. Discharges from wastewater treatment plants are ending up in different environmental compartments contaminating receiving media $[2,12,19-22]$. Based on the above it is apparent that research is urgently required on 
tertiary treatment processes, which may lead to removal of these pollutants in municipal, hospital and industrial wastewaters. Advanced oxidation processes (AOP) and mainly the electro-chemical advanced oxidation processes (EAOP) are being prominent in this field since they have the capacity to remove many compounds that are refractory to biological treatment $[23,24]$.

The electro-Fenton process (E-Fenton) is one of those EAOP processes that have been widely studied for the removal of biorefractory organic pollutants. The process is based on the electrochemical production of hydrogen peroxide $\left(\mathrm{H}_{2} \mathrm{O}_{2}\right)$ in the cathode via a reduction reaction of oxygen involving 2 electrons (Equation 1):

$\mathrm{O}_{2}+2 \mathrm{H}^{+}+2 \mathrm{e}^{-} \rightarrow \mathrm{H}_{2} \mathrm{O}_{2}$

Several cathode materials with high surface area such as carbon-PTFE gas $\left(\mathrm{O}_{2}\right.$ or air $)$ diffusion electrodes [25,26], carbon felt [27], carbon sponge [28] and reticulated vitreous carbon RVC [29] and carbon nanotubes [30] have been applied for $\mathrm{H}_{2} \mathrm{O}_{2}$ electrogeneration in the E-Fenton process. The use of carbon cathodes is of interest because carbon is nontoxic and exhibits a high overpotential for $\mathrm{H}_{2}$ evolution (good current efficiency) and low catalytic activity for $\mathrm{H}_{2} \mathrm{O}_{2}$ decomposition. Carbon material has also good stability, conductivity, and chemical resistance [24].

Subsequently to reaction (1), hydrogen peroxide reacts with $\mathrm{Fe}^{2+}$ (Equation 2) to produce the hydroxyl radical $\left({ }^{\circ} \mathrm{OH}\right)$ which is powerful oxidant and is able to oxidise organic pollutants until their ultimate oxidation state, i.e., mineralization to $\mathrm{CO}_{2}$, water and inorganic ions $[27,31]$.

$\mathrm{Fe}^{2+}+\mathrm{H}_{2} \mathrm{O}_{2} \rightarrow \mathrm{Fe}^{3+}+\mathrm{OH}^{-}+\cdot \mathrm{OH} \cdot \mathrm{OHOH}^{*}$ 
The $\mathrm{Fe}^{3+}$ ions formed in Equation (2) are reduced electrochemically to regenerate ferrous ions that can further catalyse the Fenton reaction (Equation 3):

$$
\mathrm{Fe}^{3+}+\mathrm{e}^{-} \rightarrow \mathrm{Fe}^{2+}
$$

This process is advantageous in comparison to the chemical Fenton process due to its high efficiency in the utilization of Fenton reagents (e.g. $\mathrm{H}_{2} \mathrm{O}_{2}$ ) and due to the cost reduction related with the storage and transport of chemicals. Although the electroFenton process has been successfully applied to the treatment of a very large group of organic pollutants during the last decade, studies on NSAIDs are scarce [23]. Furthermore, the material (e.g., expensive electrode for example Boron Doped Diamond or platinum) and operational costs (e.g., electric energy consumption) are still high, which may seriously hinder the practical application. Recently the combination of the electro-Fenton process with bioelectrochemical processes such as microbial fuel cell (MFC) has been suggested as a promising alternative solution [32,33]. The process has been recently named as bio-electro-Fenton process which shows several advantages in relation to the chemical and/or electro-chemical Fenton processes [34,35].

In MFC, $\mathrm{H}_{2} \mathrm{O}_{2}$ was generated at a concentration of $39 \mathrm{mM}$ or $1.9 \mathrm{~kg} \mathrm{H}_{2} \mathrm{O}_{2} \mathrm{~m}^{-3}$ day $^{-1}$ [36] rendering this process a promising alternative for the industrial production of this reagent. Nevertheless until now the production of $\mathrm{H}_{2} \mathrm{O}_{2}$ in these systems is not yet sufficient for the needs of wastewater treatment. An improvement in the production of $\mathrm{H}_{2} \mathrm{O}_{2}$ may be achieved by imposing a small power potential in the cathode in order to facilitate the production of $\mathrm{H}_{2} \mathrm{O}_{2}$ as was suggested by Rozendal [36]. Recently, microbial electrolytic cells (MEC) were proposed as an efficient alternative for the production of $\mathrm{H}_{2} \mathrm{O}_{2}$ [37]. Although MEC require an electric energy supply (0.2-0.8 V) instead of producing electric energy, the $\mathrm{H}_{2} \mathrm{O}_{2}$ production rate is around 2 orders of 
magnitude compared to that of MFCs [36]. It has also been demonstrated that the $\mathrm{H}_{2} \mathrm{O}_{2}$ production in a MEC mode powered by a MFC is higher than that obtained in a MFC mode [38]. This process of degradation of organic compounds is highly attractive in the present framework for the treatment of wastewater containing emerging micropollutants such as the NSAIDs. To the best of our knowledge, no investigation has been reported related to the degradation of NSAIDs or other pharmaceutical compounds in a MEC based bio-electro-Fenton system.

In this study, the feasibility of the bio-electro-Fenton process for the removal of NSAIDs present in municipal wastewater at low concentrations (approximately $40 \mu \mathrm{g} \mathrm{L}$ ${ }^{1}$ ) was demonstrated. In addition, the effects of operational parameters (i.e. cathode $\mathrm{pH}$, applied voltage, air flow, NSAIDs concentration, $\mathrm{Fe}^{2+}$ concentration and reaction time) upon the efficiency of removal and reaction rates were examined. This work provides a new approach to remove pharmaceuticals from domestic wastewaters.

\section{MATERIALS AND METHODS}

\subsection{Reactor setup and operation}

A laboratory scale rectangular bio-electrochemical system (BES) consisting of two chambers was developed on the basis of non-conducting polycarbonate sheets. The two chambers $(5 \mathrm{~cm} \times 5 \mathrm{~cm} \times 4 \mathrm{~cm}$ for each) were separated by a bipolar membrane (fumasep ${ }^{\circledR}$ FBM bipolar membrane PK- reinforced, FUMATECH BWT GmbH, Germany) in order to maintain a low cathode $\mathrm{pH}$ and avoid $\mathrm{H}^{+}$drop in the anode (Figure 1). The reactor was assembled with stainless steel screws and sealed with rubber gaskets to avoid leakage. Plastic tubing (internal diameter $0.6 \mathrm{~cm}$ ) was placed on the top of each chamber for feeding and sample collection. The total and working volume of anode chamber was 100 and $95 \mathrm{~mL}$, respectively. The total and working volume of the cathode chamber was 100 and $80 \mathrm{~mL}$, respectively. The anode was made of a carbon 
brush (diameter $5.9 \mathrm{~cm}$, length $6.9 \mathrm{~cm}$, Mill-Rose, USA) which was pretreated at $450^{\circ} \mathrm{C}$ for 30 minutes. Anodic biofilm was cultivated with sodium acetate $(20 \mathrm{mM})$ as substrate and wastewater collected from primary clarifier (Lyngby Wastewater Treatment Plant, Copenhagen, Denmark); after biofilm development the anode was transferred to the MEC [32]. Two different electrodes were submerged in the cathode chamber, one was a graphite plate (projected surface area of $9 \mathrm{~cm}^{2}$ ) as suggested by ElHanafi [39] and the other was $\mathrm{Ag} / \mathrm{AgCl}$ reference electrode $(+0.197$ V vs SHE, Pine Instrument Company, USA). The distance between anode and cathode was approximately $3 \mathrm{~cm}$. The electrodes were connected with a titanium wire with $1 \mathrm{~mm}$ diameter through an external resistance of $0.1 \Omega$ and an analog digital data logger. Voltage (V) was monitored with 30 min intervals using a multimeter (model 2700, Keithley Instruments, Inc., Cleveland, OH, USA) connected to a computer.

The anode was inoculated with a wastewater collected from a primary clarifier (Lyngby Wastewater Treatment Plant, Copenhagen, Denmark) in mixture with $5 \mathrm{~mL}$ of sodium acetate solution $(0.012 \mathrm{M})$. The mixture of wastewater and sodium acetate was bubbled with nitrogen for 20 minutes and then the anodic chamber was sealed to keep anaerobic conditions. According to El-Hanafi [39] a catholyte $\mathrm{Na}_{2} \mathrm{SO}_{4}$ solution (80 mL, $0.050 \mathrm{M}$ ) spiked with NSAIDs solution according to the desired concentrations was injected in the cathode chamber. $\mathrm{FeSO}_{4}$ in powder form was added to achieve the desired concentration and the $\mathrm{pH}$ was adjusted to the desired values with a $\mathrm{H}_{2} \mathrm{SO}_{4}$ solution (3 M). The cathodic solution was magnetically stirred at $300 \mathrm{rpm}$ to ensure complete mixing. The cathode chamber was continuously bubbled with air by means of a peristaltic pump (OLE DITCH, Instrument Makers APS, Denmark) to supply the oxygen needed for generation of $\mathrm{H}_{2} \mathrm{O}_{2}$. 
Experiments were carried out in batch mode to assess the effect of different operating conditions: catholyte $\mathrm{pH}, \mathrm{FeSO}_{4}$ concentration in catholyte, air flow in cathode chamber, applied voltage, NSAIDs concentration in catholyte and reaction time. All the experiments were carried out in duplicates at atmospheric pressure and ambient temperature $\left(25 \pm 5^{\circ} \mathrm{C}\right)$. A voltage of $0.5 \mathrm{~V}$ was applied to the reactor except in the experiments with different voltages $(0.3,0.7$ and $0.9 \mathrm{~V})$ [36].

In all experiments, $3 \mathrm{~mL}$ samples were collected from the cathode chamber every hour for immediate determination of $\mathrm{pH}$ and $\mathrm{H}_{2} \mathrm{O}_{2}$ concentration; for determination of NSAIDs concentrations the samples were kept at $-18^{\circ} \mathrm{C}$ until used.

Between experiments the reactors were maintained with $90 \mathrm{~mL}$ wastewater and $5 \mathrm{~mL}$ sodium acetate $(0.012 \mathrm{M})$ in the anode and $80 \mathrm{~mL} \mathrm{Na}_{2} \mathrm{SO}_{4}(0.05 \mathrm{M})$ solution in the cathode chamber with magnetic stirring, air supply and an applied voltage of $0.5 \mathrm{~V}$. The reactors were kept in the mentioned conditions in order to keep the anodic biofilm alive and foster the production of electricity so that the start-up of the following experiments was straightforward.

\subsection{Chemicals}

All pharmaceuticals reference standards of analytical grade $(>98 \%)$ were purchased from different suppliers (Table S1, Supplementary Data). A stock solution of the four pharmaceuticals (i.e., diclofenac, ibuprofen, ketoprofen and naproxen) was prepared in ethanol (Merck Darmstadt, Germany). All other chemicals were purchased from SigmaAldrich Denmark ApS and were used as received.

\subsection{Chemical analysis}

Hydrogen peroxide was analysed by the colorimetric method using potassium titanium oxide oxalate which forms the yellow pertitanic acid complex in presence of hydrogen 
peroxide. The coloured complex was measured spectrophotometrically at $400 \mathrm{~nm}$ (Spectronic 20D+, Thermo Scientific) and the measuring range was 0.05-90 $\mathrm{mg} \mathrm{H}_{2} \mathrm{O}_{2}{ }^{-1}$ [40].

The method used for analysis of the pharmaceutical compounds was based on Hey [41]. However the derivatization procedure was changed according to Samaras [42]. In brief, the sample was acidified by adding phosphate buffer $(5.4 \mathrm{M} ; 10 \mathrm{~mL}$ buffer $\mathrm{L}^{-1}$ sample) to $\mathrm{pH} 3$ and surrogate standard was added. Afterwards, the samples were extracted using Oasis ${ }^{\circledR b} 3 \mathrm{cc}(60 \mathrm{mg})$ SPE columns (Waters, Denmark). The SPE columns were frozen before being transferred to a freeze dryer. When dry, the columns were eluted with $2 \mathrm{~mL}$ ethyl-acetate which afterwards was reduced to approximately $100 \mu \mathrm{L}$ under a gentle stream of nitrogen. The samples were transferred to GC vials and then evaporated completely to dryness. Afterwards, $10 \mu \mathrm{L}$ anhydrous pyridine and $50 \mu \mathrm{L} \quad \mathrm{NXO}-\mathrm{bis}($ trimethylsilyl) trifluoroacetamide with $1 \%$ trimethylchlorosilane (BSTFA+TMCS, 99:1, Supeljoco 33155-U, Sigma Denmark) were added. The vials were capped and shaken for $1 \mathrm{~min}$ and heated in an oven at $70{ }^{\circ} \mathrm{C}$ for $30 \mathrm{~min}$. Finally, the pharmaceuticals were quantified by GC-MS (Agilent GC 6890 N, MSD 5973 N utilizing a CombipAL from CTC analytics as auto sampler).

The COD, $\mathrm{pH}$ were analysed by standard methods as described previously [43]. Samples from the cathode were collected every hour and immediately analysed for $\mathrm{pH}$ and $\mathrm{H}_{2} \mathrm{O}_{2}$.

\subsection{Electrochemical measurements and calculations}

The system was monitored using a precision multimeter and a data acquisition system (Model 2700, Keithly Instruments, Inc.). In the indirect electrochemical oxidation process it is known that the reaction between organic compounds and hydroxyl radicals follows a pseudo first-order kinetics [44]. In order to determine the kinetic constants for 
the removal of the pharmaceuticals the normalised remaining concentration of each compound at each time moment was fitted with a first-order kinetic model (Equation 4) [45] and apparent rate constants $\left(\mathrm{k}_{\text {app }}\right)$ were determined. All curve fitting was conducted in Prism 5, Graph Pad.

$\frac{\mathrm{C}}{\mathrm{C}_{0}}=\exp ^{\left(-k_{a p p} \mathrm{t}\right)}$

\section{RESULTS AND DISCUSSION}

The bio-electro-Fenton degradation of the four NSAIDs compounds studied in this work followed pseudo-first order reaction. The results of the evolution of $\mathrm{C} / \mathrm{C}_{0}$ with time for all the tests performed in this work were adjusted to the equation of pseudo-first order kinetics (Equation 4), see Figure S1 (Supplementary Data). The effects of the operating parameters were studied in relation to the apparent rate constant $\left(\mathrm{k}_{\mathrm{app}}\right)$ and removal efficiency. Linear regression of results $\mathrm{C} / \mathrm{C}_{0}$ versus time from control experiments performed at open circuit with and without airflow in the cathode compartment resulted in slopes not significantly different from zero $(\mathrm{p}>0.5)$.

\subsection{Effect of initial catholyte $\mathrm{pH}$}

The efficiency of the Fenton reaction depends upon various factors such as temperature, $\mathrm{pH}$, catalyst concentration, which control the forming of $\mathrm{H}_{2} \mathrm{O}_{2}$ the production of $\left({ }^{\circ} \mathrm{OH}\right)$ and the regeneration of $\mathrm{Fe}^{2+}$ from the ferric ions produced in the process (Equation 3). The catalytic activity of the iron species is determined mainly by the $\mathrm{pH}$ of the cathodic solution. $\mathrm{pH}$ range between 2 and 4 has been widely observed as the optimum for the electro-Fenton process [45].

In this work the effect of catholyte $\mathrm{pH}$ upon the degradation of the NSAIDs substrates was studied at initial NSAIDs concentration of $40 \mu \mathrm{g} \mathrm{L}^{-1}$ of each compound, an air flow 
of $8 \mathrm{~mL} \mathrm{~min}^{-1}$, applied voltage of $0.5 \mathrm{~V}$ and $\mathrm{FeSO}_{4} 5 \mathrm{mM}$. The influence of $\mathrm{pH}$ upon the degradation of the substrates was studied for initial $\mathrm{pH}$ of 1, 2, 3, 4 and 5.

The $\mathrm{pH}$ variation greatly affected the NSAIDs removal as shown in Figure 2 . The value of the apparent removal constant $\left(\mathrm{k}_{\mathrm{app}}\right)$ and final removal efficiency after $5 \mathrm{~h}$ reaction period raised with the raising of $\mathrm{pH}$ value from 1 to 2 . For $\mathrm{pH}$ values above 2, a decrease in the apparent reaction rate was observed for all the studied compounds. According to previous electro-Fenton studies [31,44], the optimum $\mathrm{pH}$ is between 2.8 and 3.0 where the ${ }^{\circ} \mathrm{OH}$ may be propagated by the catalytic behavior of the $\mathrm{Fe}^{3+} / \mathrm{Fe}^{2+}$ couple. At a $\mathrm{pH}$ of 2.8 the available $\mathrm{Fe}^{2+}$ in the reaction media is at its maximum, resulting in the highest rate for the Fenton reaction. On the other hand, at a $\mathrm{pH}$ above 5 the $\mathrm{Fe}(\mathrm{III})$ species might precipitate as $\mathrm{Fe}(\mathrm{OH})_{3}$ which could diminish the amount of catalyst in the solution and break down $\mathrm{H}_{2} \mathrm{O}_{2}$ into $\mathrm{O}_{2}$ and $\mathrm{H}_{2} \mathrm{O}$. The low removals efficiency at $\mathrm{pH} 1$ could be explained by a diffusion of protons from the cathode chamber into the anode chamber resulting in an acidic environment that may affect the bioactivity of the anode bacteria [46]. As can be seen in Table 1, the majority of electroFenton studies for the degradation of NSAIDs were carried out at $\mathrm{pH}$ 3. For a bioelectro-Fenton process treating azo-dye wastewater, an optimum $\mathrm{pH}$ of 3 was also reported [38]. Although the recommended $\mathrm{pH}$ value for the electro-Fenton degradation of organic substrates is around 3, some works found a lower optimum $\mathrm{pH}[31,44]$. For example, Ling [47] observed that in an electro-Fenton process the concentration of $\mathrm{H}_{2} \mathrm{O}_{2}$ at $\mathrm{pH} 2$ reached a maximum value of $88.63 \mu \mathrm{g} \mathrm{L}{ }^{-1}$ which was about 8 times higher than that observed at $\mathrm{pH} 5$.

On the other hand, at higher $\mathrm{pH}$ there may not be sufficient protons to participate in the formation of $\mathrm{H}_{2} \mathrm{O}_{2}$ or the catholyte may not be acidic enough to prevent the precipitation of ferric ions as oxide-hydroxides of iron at $\mathrm{pH}$ above 4 [46]. It has also been discussed 
[45] that at high $\mathrm{pH}$ values pollutant removal may take place by electrocoagulation where the pollutants are removed by electrostatic attraction and/or complexation reactions due to the conversion of $\mathrm{Fe}^{3+}$ and $\mathrm{Fe}^{2+}$ into structures of the type $\mathrm{Fe}(\mathrm{OH})_{\mathrm{n}}$. Apparently these phenomena happened in the present study since substrates removal was still observed at $\mathrm{pH}$ values above 3 ( $\mathrm{pH} 4$ and 5) (Figure S2a). This enhanced removal of pharmaceuticals due to electrocoagulation phenomena at higher $\mathrm{pH}$ was observed only at the end of the batch tests which may be explained by the high initial $\mathrm{pH}$ coupled with the natural $\mathrm{pH}$ increase at the end of the reaction period due $\mathrm{H}^{+}$ consumption for the production of ${ }^{\bullet} \mathrm{OH}$ radicals (Equation 1). At $\mathrm{pH} 2$ the residual $\mathrm{H}_{2} \mathrm{O}_{2}$ concentration reached a minimum (Figure S3a) suggesting a fast consumption by reaction with $\mathrm{Fe}^{2+}$ to form ${ }^{\bullet} \mathrm{OH}$ radicals (Equation 2) which is in accordance with the values of $\mathrm{k}_{\mathrm{app}}$ and removal efficiencies.

Fenton process is more sensitive to $\mathrm{pH}$ values than the production of $\mathrm{H}_{2} \mathrm{O}_{2}$ which may be produced at high rate at neutral $\mathrm{pH}$. The effects of $\mathrm{pH}$ were supposedly upon the Fenton reaction for forming ${ }^{\circ} \mathrm{OH}$ radicals (equation 2) and not upon the production of $\mathrm{H}_{2} \mathrm{O}_{2}$ (equation 1) since at higher $\mathrm{pH}$ values $(\mathrm{pH}=5)$ there was a high $\mathrm{H}_{2} \mathrm{O}_{2}$ content in the cathode (see Fig S3a) suggesting that $\mathrm{H}_{2} \mathrm{O}_{2}$ was formed but not consumed at the same rate as for lower $\mathrm{pH}$ values. 
Table 1 - Previous studies on electro-Fenton degradation of NSAIDs.

\begin{tabular}{|c|c|c|c|c|c|c|}
\hline Compound & Experimental setup and conditions & Matrix & Initial concentration & Removal & $\mathrm{k}_{\text {app }}$ & Reference \\
\hline Ibuprofen & $\begin{array}{l}\text { Undivided cell equipped with a } \mathrm{GDE}\left(\mathrm{O}_{2}\right. \\
\text { diffusion) as cathode, and } \mathrm{Pt} \text { or } \mathrm{BDD} \\
\text { anode; constant current density } 33.3 \mathrm{~mA} \\
\mathrm{~cm}^{-2} ; \mathrm{pH}=3 ; \mathrm{T}=25^{\circ} \mathrm{C}\end{array}$ & $\begin{array}{l}\text { Artificial aqueous } \\
\text { solution }\end{array}$ & $41 \mathrm{mg} \mathrm{L}^{-1}$ & & & {$[48]$} \\
\hline Ibuprofen & $\begin{array}{l}\text { Undivided cell, } \mathrm{Pt} \text { or } \mathrm{BDD} \text { anode and } \\
\text { carbon-PTFE cathode }\left(\mathrm{O}_{2} \text { diffusion }\right. \\
\text { cathode }) ; 0.05 \mathrm{M} \mathrm{Na}_{2} \mathrm{SO}_{4} ; 33.3 \mathrm{~mA} \mathrm{~cm} \text {; } \\
\mathrm{Fe}^{2+}=0.5 \mathrm{mM} ; \mathrm{pH}=3\end{array}$ & $\begin{array}{l}\text { Artificial aqueous } \\
\text { solution }\end{array}$ & $41 \mathrm{mg} \mathrm{L}^{-1}$ & $\begin{array}{l}\text { Pt anode: } 58 \% \\
\text { (DOC) } \\
\text { BDD anode: } \\
81 \% \text { (DOC) }\end{array}$ & $\begin{array}{l}1.86 \times 10^{-3} \mathrm{~s}^{-1} \\
\text { and } 2.06 \times 10^{-3}\end{array}$ & [48] \\
\hline Ibuprofen & $\begin{array}{l}\text { Undivided cell, graphite felt cathode and } \mathrm{Pt} \\
\text { or BDD as anode; } 0.05 \mathrm{M} \mathrm{NaSO}_{4} \text { or } 0.1 \mathrm{M} \\
\mathrm{NaCl} ; \mathrm{I}=50-500 \mathrm{~mA} ; \mathrm{Fe}^{3+}=0.05-0.5 \mathrm{mM} \text {; } \\
\mathrm{pH}=3 ; \mathrm{T}=(23 \pm 2)^{\circ} \mathrm{C}\end{array}$ & Acetonitrile/water & $0.2 \mathrm{mM}\left(41.25 \mathrm{~g} \mathrm{~L}^{-1}\right)$ & $\begin{array}{l}\text { BDD anode: } \\
96 \% \\
\text { mineralization }\end{array}$ & $1 h^{-1}-27 h^{-1}$ & [49] \\
\hline Ibuprofen & $\begin{array}{l}\text { Undivided cell Ti/MMO cathode and } \\
\text { anode; } \mathrm{Na}_{2} \mathrm{SO}_{4} 2 \mathrm{mM} \text {; Constant current } 40 \\
\mathrm{~mA} ; \mathrm{pH}=3 ; 6.9 \mathrm{mg} \mathrm{L}^{-1} \mathrm{Fe}^{2+} ; \mathrm{T}=(25 \pm \\
1)^{\circ} \mathrm{C}\end{array}$ & $\begin{array}{l}\text { Artificial aqueous } \\
\text { solution }\end{array}$ & & $\sim 100 \%$ & $0.109 \min ^{-1}$ & {$[50]$} \\
\hline Diclofenac & $\begin{array}{l}\text { Stack of pairs of anodic and cathodic } \\
\text { electrodes, by impregnating catalytic ferric } \\
\text { ions and/or iron nanoparticles on the } \\
\text { cathode surface; recirculation liquid flow- } \\
\text { rate } 300 \mathrm{~mL} / \mathrm{min} ; \mathrm{Na}_{2} \mathrm{SO}_{4} \text { as catholyte; } \\
\mathrm{Fe} / \mathrm{C}=10 \%-30 \% ; \mathrm{pH}=3 ; \mathrm{T}=25^{\circ} \mathrm{C}\end{array}$ & $\begin{array}{l}\text { Artificial aqueous } \\
\text { solution }\end{array}$ & Range of $\mu \mathrm{g} \mathrm{L}^{-1}$ & $37.2 \%$ to $82.4 \%$ & & [51] \\
\hline Diclofenac & $\begin{array}{l}\text { Flow-by undivided cell; GDE as cathode; } \\
\text { DSA-Cl }{ }_{2} \circledR \text { as anode; } \mathrm{K}_{2} \mathrm{SO}_{4} 0.1 \mathrm{M} \text { as } \\
\text { catholyte; } 10 \mathrm{mM} \mathrm{FeSO}_{4} ; \mathrm{pH}=5.8 \text {; } \\
\text { constant current } 1,0 ; 2,0 ; 3,0 \text { e } 4,0 \mathrm{~A} \text { in } \\
\text { relation to the cathode; } \mathrm{T}=\text { not reported }\end{array}$ & $\begin{array}{l}\text { Artificial aqueous } \\
\text { solution }\end{array}$ & $200 \mathrm{mg} \mathrm{L}^{-1}$ & $99.4 \%$ & & {$[52]$} \\
\hline
\end{tabular}


Diclofenac iron-impregnated carbon electrodes (Heterogeneous Fenton reaction) Anode CFm; Cathode CFm-nFe; $\mathrm{Na}_{2} \mathrm{SO}_{4} 0.05 \mathrm{M}$; $1.0 \mathrm{~V} / \mathrm{Ag} / \mathrm{AgCl} ;$ Neutral $\mathrm{pH} ; \mathrm{T}=25 \mathrm{C}$

Ketoprofen Undivided cell; $\mathrm{Pt}$ and $\mathrm{BDD}$ anode; 3D Artificial aqueous carbon felt cathode; $\mathrm{Na}_{2} \mathrm{SO}_{4} 0.05 \mathrm{M} ; \mathrm{pH}=3$; $\mathrm{FeSO}_{4}=0.05-1 \mathrm{mM} ; \mathrm{I}=100 \mathrm{~mA}$

Naproxen

Artificial aqueous
solution solution

BDD cathode, $100 \mathrm{~mA}, 4-8$ hours, Artificial aqueous $(23 \pm 2)^{\circ} \mathrm{C}, \mathrm{pH}=3$
$1.3 \mathrm{mg} \mathrm{L}^{-1} \quad 63.7 \%$

$0.198 \mathrm{mM}$

$\sim 100 \%$ 


\subsection{Effect of initial $\mathrm{Fe}^{2+}$ concentration}

In the bio-electro-Fenton system, the iron concentration in the cathode is one of the influential parameters affecting the oxidation of organic pollutants. It has been found that a low $\mathrm{Fe} / \mathrm{H}_{2} \mathrm{O}_{2}$ molar ratio favoured the COD oxidation process [56]. In this work, the effect of initial concentration of $\mathrm{FeSO}_{4}(5,7.5$ and $10 \mathrm{mM})$ in the catholyte was assessed upon a set of fixed reaction parameters $\left(40 \mu \mathrm{g} \mathrm{L}^{-1}\right.$ of NSAIDs, airflow of $8 \mathrm{~mL}$ $\min ^{-1}$, applied voltage of $0.5 \mathrm{~V}$, catholyte $\mathrm{pH} 2$ and 5 hours reaction time). The optimum initial molar concentration of $\mathrm{FeSO}_{4}$ was $7.5 \mathrm{mM}$ corresponding to a mass concentration of $0.72 \mathrm{~g} \mathrm{~L}^{-1}$ (Figures 3 and S2b). The optimum Fe concentration of $7.5 \mathrm{mM}$ determined in this work is higher than what is usually reported and recommended in the literature [45]. However, higher concentrations have also been reported. Among a few studies, Wang [57] reported a much higher value of $20 \mathrm{mM}$ for the decolorization of real dyeing wastewater. This high value may be explained by the formation of iron complexes with organic compounds formed by the degradation of NSAIDs [58]. The decrease in the NSAIDs removal at a concentration of $10 \mathrm{mM} \mathrm{FeSO}_{4}$ may be due to the competing reaction of $\mathrm{Fe}^{2+}$ with the ${ }^{\bullet} \mathrm{OH}$ radical to form $\mathrm{Fe}^{3+}$ (Equation 5).

$\mathrm{Fe}^{2+}+\cdot \mathrm{OH} \rightarrow \mathrm{Fe}^{3+}+\mathrm{OH}^{-}$

At a high $\mathrm{Fe} / \mathrm{H}_{2} \mathrm{O}_{2}$ molar ratio, the existence of a lower amount of $\mathrm{H}_{2} \mathrm{O}_{2}$ or an excess amount of $\mathrm{Fe}$ ions in the reaction medium causes a low production of hydroxyl radicals and reduction in the degradation of organic matters [59]. Beltran de Heredia [60] reported that an increase in COD removal efficiency was obtained for a molar ratio of $\mathrm{Fe} / \mathrm{H}_{2} \mathrm{O}_{2}=0.1$ and then decreased with an increase in the $\mathrm{Fe} / \mathrm{H}_{2} \mathrm{O}_{2}$ ratio of 0.3. Similar results have been found in an electro-Fenton process treating amaranth [34]. For higher substrate concentrations there was a raise in pollutant degradation (80-100\%) with the increasing of Fe dosage $(0.1$ to $1.0 \mathrm{mM})$. Further increases of Fe dosage to 3 and $5 \mathrm{mM}$ 
lead to a drop in degradation efficiency from $80 \%-100 \%$ to $50 \%-80 \%$. Pozza [61] suggested a $\mathrm{Fe} / \mathrm{H}_{2} \mathrm{O}_{2}$ molar ratio of 2 for reaching the highest reaction rate and removal efficiency in an electro-Fenton process used for the oxidation of phosphorus in the form of hypophosphite compounds. It was observed that at a $\mathrm{pH}$ of 1.8-2.0 a molar ratio of $\mathrm{Fe}^{2+} / \mathrm{H}_{2} \mathrm{O}_{2}$ of 2 led to an improvement in the reaction both in terms of rate and product yield. In this work the residual $\mathrm{H}_{2} \mathrm{O}_{2}$ concentration (Figure $\mathrm{S} 3 \mathrm{~b}$ ) reached a minimum value with $\mathrm{FeSO}_{4}$ dosage of $7.5 \mathrm{mM}$ implicating a high rate of consumption to form ${ }^{\bullet} \mathrm{OH}$ radicals.

In this work the final concentration of $\mathrm{Fe}$ in the treated effluent was not measured yet it is envisioned that after neutralization the final effluent will meet discharge regulations due to iron precipitation.

Despite its simplicity the main weakness of the Fenton process is the formation of sludge during neutralization after the Fenton oxidation [62]. The electro-fenton process may diminish this problem due to the constant regeneration of $\mathrm{Fe}^{2+}$ that takes place in the cathode (Equation 3). The yield of sludge and its composition depend upon the proportion and the volumes of the added reagents. To minimize the sludge production in the Fenton process it is possible to use heterogeneous catalysts and reuse the iron from the sludges [63]. In the case of heterogeneous catalysts natural minerals have been used, clays containing iron, iron immobilized in solid supports and zero-valent iron [63]. Yoo et al. (2001) suggested the reutilization of the produced sludges from Fenton oxidation in a coagulation process [64]. The produced sludge may be reduced up to $50 \%$ as well as the used coagulant [65]. Cao et al. (2009) presented a simple method to recover the iron catalyst from sludge containing iron hydroxides to be used in the oxidation of industrial wastewater [66]. In this method sludge is denatured, dried and baked at a temperature of $350-400^{\circ} \mathrm{C}$ and subsequently the residual solids were dissolved in 
sulphuric acid to form a reusable catalyst for Fenton and Fenton-like reactions. The reuse routines mentioned above are beneficial for the reduction and minimization of iron-containing sludge compared with traditional treatment processes. As an alternative to the use of Fe to produce radicals it is also possible to use UV thus avoiding the problem of iron sludge and treated effluent with $\mathrm{Fe}$ content above discharge limits. Further developments of the system tested in this work may address this issue.

\subsection{Effect of airflow rate at the cathode}

The concentration of dissolved oxygen (DO) influences the rate of $\mathrm{H}_{2} \mathrm{O}_{2}$ production at the cathode and thus indirectly influence the production of the radical ${ }^{\circ} \mathrm{OH}$. Thus, airflow rate which determined the DO level at the cathode is one of the major factors that affect the electro-Fenton process.

In this section, the effect of different airflow rates $\left(0,8,14\right.$ and $\left.20 \mathrm{~mL} \mathrm{~min}^{-1}\right)$ on the pharmaceuticals removal was explored without changing other operational parameters (initial NSAIDs concentration of $40 \mu \mathrm{g} \mathrm{L}^{-1}$, applied voltage of $0.5 \mathrm{~V}$ and $\mathrm{FeSO}_{4}$ of $5 \mathrm{mM}$, catholyte $\mathrm{pH}$ of 2 and reaction time of 5 hours). The calculated values of oxygen flow based on the airflow ranged from 0 to $0.05 \mathrm{~mL} \mathrm{O}_{2} \mathrm{~min}^{-1} \mathrm{~mL}^{-1}$, which was about one to fifty orders of magnitude lower than that reported in previous studies $[61,67]$. Zhang [38] operated their reactor at even lower airflow of $10 \mathrm{~mL} \mathrm{~min}^{-1}$ for a cathode working volume of $250 \mathrm{~mL}$ which corresponds roughly to $0.008 \mathrm{~mL} \mathrm{O}_{2} \mathrm{~min}^{-1} \mathrm{~mL}^{-1}$. As can be seen from Figure 4, the apparent rate constant $\left(\mathrm{k}_{\mathrm{app}}\right)$ was depending on the airflow rate and reached to its maximum value at air flow of $8 \mathrm{~mL} \mathrm{~min}^{-1}\left(0.021 \mathrm{~mL} \mathrm{~min}^{-}\right.$

$\left.{ }^{1} \mathrm{~mL}^{-1}\right)$. This finding was similarly to the previous studies $[61,67]$. The results of the removal efficiency after 5 hours reaction time (Figure S2c) confirm the deleterious effect of excess air on the treatment process. The average $\mathrm{H}_{2} \mathrm{O}_{2}$ concentration in cathode solution increased with the increasing of airflow rate (Figure S3c). This trend ceased 
when the airflow rate was over $8 \mathrm{~mL} \mathrm{~min}^{-1}$, which could be due to the saturated oxygen level in the catholyte. No measurements were made of the oxygen concentration in the cathode but the results obtained in this work allow the inference of oxygen saturation in the catholyte solution, since for airflow values above $8 \mathrm{~mL} \mathrm{~L}^{-1}$ the values of $\mathrm{H}_{2} \mathrm{O}_{2}$ were almost constant (see Fig. S3C). Another reason for the lower $k_{a p p}$ and removal efficiencies obtained with higher air flows might be that any airflow rate faster than 8 $\mathrm{mL} \min ^{-1}$ would release gas with larger bubbles in size, which was detrimental to the oxygen adsorption onto the cathode [68], which is confirmed by the ceasing tendency of $\mathrm{H}_{2} \mathrm{O}_{2}$ rise when air flow was higher than $8 \mathrm{~mL} \mathrm{~L}^{-1}$.

\subsection{Effect of applied voltage}

A higher voltage originates a higher current and it is expected that this enhanced electron flow improves reaction rate. Thus, different applied voltages of $0.3 \mathrm{~V}, 0.5 \mathrm{~V}$, $0.7 \mathrm{~V}$ and $0.9 \mathrm{~V}$ were used to assess its influence on the apparent reaction rate and removal efficiency. Experimental conditions were the following: initial NSAIDs concentration of $40 \mu \mathrm{g} \mathrm{L}^{-1}, \mathrm{FeSO}_{4} 5 \mathrm{mM}$, catholyte $\mathrm{pH}$ of 2 , airflow $8 \mathrm{~mL} \mathrm{~min}^{-1}$ and 5 hours reaction time. The results were contrary to what would be expected (Figure 5). The applied voltage of $0.3 \mathrm{~V}$ over other levels resulted in the highest apparent rate constant $\mathrm{k}_{\mathrm{app}}$ and removal efficiencies for all the compounds tested. The applied voltage of $0.9 \mathrm{~V}$ resulted in relatively higher current densities as may be seen in Figure S4.

However, the higher currents might accelerate the $\mathrm{H}_{2} \mathrm{O}_{2}$ conversion to water [68], and thereby diminishing the $\mathrm{H}_{2} \mathrm{O}_{2}$ availability for the Fenton reaction for the oxidation of the organic substrates.

\subsection{Effect of NSAIDs concentration}

The influence of the initial pharmaceuticals concentration on the system performance was investigated at different initial NSAIDs concentrations (40, 80 and $120 \mu \mathrm{g} \mathrm{L}^{-1}$ for 
each of the compounds). Other test conditions were as follows: $\mathrm{pH} 2$, applied voltage $0.5 \mathrm{~V}, \mathrm{FeSO}_{4} 5 \mathrm{mM}$, air flow $8 \mathrm{~mL} \mathrm{~min}^{-1}$ and 5 hours reaction time. The results presented in Figure 6 show that the rate constants increased with the increasing of initial NSAIDs concentration. The $k_{\text {app }}$ for Diclofenac at an initial concentration of $120 \mu \mathrm{g} \mathrm{L}^{-1}$ was higher compared to other pharmaceuticals with any tested concentration. This may be due to the ease of oxidation of Diclofenac by the electro-Fenton reactions.

\subsection{The effect of reaction time on removal efficiencies}

In order to assess if longer reaction times could improve removal efficiencies tests were performed for reaction times up to 51 hours with the following experimental conditions: initial NSAIDs concentration of $40 \mu \mathrm{g} \mathrm{L}^{-1}, \mathrm{pH} 2$, applied voltage $0.5 \mathrm{~V}, \mathrm{FeSO}_{4} 5 \mathrm{mM}$, airflow rate of $8 \mathrm{~mL} \mathrm{~min}^{-1}$. As shown in Figure 7, prolonging the reaction time from 5 to 11 hours slightly improved the removal efficiencies for Diclofenac and Ibuprofen, but dramatically raised the removal efficiency for Naproxen from $75 \%$ to $94 \%$ and Ketoprofen from $59 \%$ to $78 \%$. A raise in reaction time up to 51 hours benefited the removal efficiency of Ketoprofen from $78 \%$ (11 hours) to $96 \%$ (51 hours), while the effect upon the other compounds was negligible.

The effect of longer reaction times upon the removal efficiencies was observed mainly for ketoprofen and naproxen which were the two most difficult compounds to degrade according to the values of $\mathrm{k}_{\mathrm{app}}$ from the experiments done in this work. This means that

their degradation mechanisms are slower and that a prolonged reaction time results in improved removal efficiency. Information of the degradation pathways of NSAIDs is beyond the scope of this work but they have been reported in the literature specifically for ketoprofen [54], naproxen [69], ibuprofen [70] and diclofenac [70]. 


\subsection{Application to municipal wastewater}

It is known that the complexity of the matrix may affect the electro-Fenton process, yet no studies from the literature report the electro-Fenton degradation of NSAIDs in real wastewater samples and the majority of the studies were being done on water matrixes (Table 1) [48,50-55]. Thus, experiments were performed with real wastewater after secondary biological treatment (Lyngby Wastewater Treatment Plant, Copenhagen, Denmark) for the degradation of the NSAIDs compounds. The characteristics of the wastewater were as follows: $\operatorname{COD} 186 \mathrm{mg} \mathrm{L}^{-1} ; \mathrm{pH} 7.9$; conductivity $1.3 \mathrm{mS} \mathrm{cm}^{-1}$; nitrogen $0.08 \mathrm{~g} \mathrm{NH}_{4}{ }^{+}-\mathrm{N} \mathrm{L}{ }^{-1}$; phosphorus $0.01 \mathrm{~g} \mathrm{PO}_{4}{ }^{2-}-\mathrm{P} \mathrm{L}^{-1} ; \mathrm{Cl}^{-} 0.1 \mathrm{~g} \mathrm{~L}^{-1} ; \mathrm{SO}_{4}{ }^{2-}$ $0.03 \mathrm{~g} \mathrm{~L}^{-1}$. To eliminate interference of suspended matter with analytical methods for NSAIDs determination wastewater was previously filtered through membrane filter (Filter Membrane PTFE $0.45 \mu \mathrm{m}$, Thomas Scientific).

The initial concentrations of the NSAIDs compounds in samples of the wastewater are presented in Table 2. Due to the high variability of the NSAIDs concentrations in the wastewater the degradation tests in the bio-electro-Fenton reactor were performed with a wastewater sample spiked with a solution of NSAIDs compounds in order to attain a concentration near $40 \mu \mathrm{g} \mathrm{L}^{-1}$ of each compound.

Table 2 - Concentrations of NSAIDs in wastewater (Lyngby Wastewater Treatment Plant, Copenhagen, Denmark).

\begin{tabular}{lcc} 
Compound & $\begin{array}{c}\text { Average Concentration } \\
\left(\mu \mathrm{g} \mathrm{L}^{-1}\right)\end{array}$ & $\begin{array}{c}\mathrm{SD} \\
(\mathrm{n}=4)\end{array}$ \\
\hline Ketoprofen & 24.5 & 0.027 \\
Diclofenac & 9.2 & 0.008 \\
Ibuprofen & 33.7 & 0.016 \\
Naproxen & 33.7 & 0.026 \\
\hline
\end{tabular}

For the bio-electro-Fenton degradation studies with wastewater the same reactor and procedure were used as for the assessment of operational factors above. The $\mathrm{pH}$ of the wastewater was adjusted to $\mathrm{pH} 2$, the applied voltage was $0.5 \mathrm{~V}$, airflow rate was 
$8 \mathrm{~mL} \mathrm{~min}^{-1}, \mathrm{FeSO}_{4}$ was added to a concentration of $5 \mathrm{mM}$ and reaction time was 5 hours. The $\mathrm{k}_{\mathrm{app}}$ for the removal of the NSAIDs compounds in the raw wastewater are presented in Figure 8 together with the results of the tests under similar conditions and an initial concentration of NSAIDs of $40 \mu \mathrm{g} \mathrm{L} \mathrm{L}^{-1}$. It can be seen that for Ketoprofen, Diclofenac and Naproxen the $\mathrm{k}_{\text {app }}$ for wastewater samples are $30 \%$ to $65 \%$ lower than that obtained with distilled water samples. This fact could be due to that the organic matter presented in the wastewater may compete with the NSAIDs for the ${ }^{\bullet} \mathrm{OH}$ radical. Several authors have reported that the EAOPs showed lower oxidation capacity when used with real wastewaters $[71,72]$. If organic substances are present in the system they react in many ways with the generated hydroxyl radicals [72]. On the other hand Fenton reactions are inhibited by inorganic ions. In particular ferric iron forms complexes with phosphate which are quite insoluble in neutral or mildly acidic solutions. Moreover, sulphate, chloride and fluoride inhibit the process because these ions reduce the reactivity of ferric iron through coordination to form less reactive complexes [72]. Antonin et al. (2015) reported inhibition of Fenton's reaction in a synthetic urine matrix mainly due to the complexation of $\mathrm{Fe}^{2+}$ with organic anions, primordially $\mathrm{PO}_{4}{ }^{3-}[73]$. The phosphorus concentration of the wastewater used in this work is similar to the one used by Antonin et al. (2015) which may explain the lowering of $\mathrm{k}_{\mathrm{app}}$ of the experiments with real wastewater as compared to distilled water [73]. The decrease in the oxidation performance may also be due to a drop in the concentration of the main oxidant $\left({ }^{\circ} \mathrm{OH}\right)$ which could be related to lower specific conductivity, which causes a greater ohmic drop that ends in a less effective formation of oxidants [74].

It is important to note the difference in the rate constants since many studies on the degradation of emerging pollutants are made with synthetic water samples without considering the effects of the complex matrix of real wastewater (Table 1). These 
effects were not only observed on the reaction rates but also on the removal efficiencies (Figure S2d).

\subsection{Energy consumption and costs}

The major operating costs of electrochemical cell are associated with electric energy consumption during the process. Electrical energy consumption was calculated using equation 6:

$\mathrm{E}=\mathrm{I} \times \mathrm{V} \times \mathrm{t}$

Where E (kWh) represents the energy consumed, I (A) is the current intensity, V (V) is the voltage applied to the cell and $\mathrm{t}(\mathrm{h})$ is the total reaction time. Taking as an example a test performed to treat $80 \mathrm{~mL}$ of water with $\mathrm{pH} 2$, an applied voltage of $0.3 \mathrm{~V}$ and a total reaction time of 5 hours the energy consumption is:

$\mathrm{E}=(0.001595 \times 0.3 \times 5)=2.39 \times 10^{-3} \mathrm{kWh}$

Assuming an energy cost of $0.13 € / \mathrm{kWh}[75]$, the cost to treat $1 \mathrm{~m}^{3}$ would be $3.8 € / \mathrm{m}^{3}$. It is important to note that the energy consumption can also be lowered with green energy, like wind energy, tidal or solar, or using biogas from an anaerobic digestion reactor to produce energy to be used in the electrochemical reactor to polish the anaerobic reactor effluent [76]. Thus, incorporating renewable energy sources in the electrochemical treatment of wastewaters opens future prospects in this field.

\subsection{Comparison with other AOP technologies}

AOPs are characterized by a common chemical feature, where they utilize the highly reactive hydroxyl radicals for achieving complete mineralization of the organic pollutants into carbon dioxide and water [77]. The ${ }^{\circ} \mathrm{OH}$ radical allows the very quick 
cleavage of the aromatic rings as well as the progressive oxidation of some aliphatic carboxylic acid by-products. The degradation pathways of NSAIDs by AOP have been studied in the literature specifically for NSAIDs (see 3.6). The effectiveness of the method for degrading NSAIDs depends on the efficiency by which ${ }^{\circ} \mathrm{OH}$ is produced.

Ozonation can be used for the oxidation of several chemical organic compounds, nevertheless the process is cost and energy intensive [78]. The energy costs for ozone generation are the main expenditure for the process. Furthermore, ozone methods have a potential for the formation of bromate. Although ozonation complemented with UV is efficient in the generation of hydroxyl radicals the process is less energetically efficient for generating large quantities of hydroxyl radicals due to the low solubility of $\mathrm{O}_{3}$ in water. Thus operational costs are expected to be high. On the other hand gaseous $\mathrm{O}_{3}$ must be diffused into the source water, resulting in potential mass transfer limitations relative to $\mathrm{H}_{2} \mathrm{O}_{2}$, which is fed as a liquid solution [79] or generated onsite. The main shortcoming of ozonation is the difficult mineralization of pollutants. Heterogeneous catalysts have been found as a solution in ozonation, as well as heterogeneous photocalysis and, thus, ozonation has been also combined with photocatalysis, the electron-hole recombination decreasing and the production of hydroxyl radicals increasing $[80,81]$.

The $\mathrm{UV} / \mathrm{H}_{2} \mathrm{O}_{2}$ process has been shown very efficient on the degradation of various organic pollutants. Many successful application of $\mathrm{UV} / \mathrm{H}_{2} \mathrm{O}_{2}$ could be found in the literature [82-85]. The advantage of $\mathrm{UV} / \mathrm{H}_{2} \mathrm{O}_{2}$ is that the $\mathrm{H}_{2} \mathrm{O}_{2}$ is the only chemical that needs to be added, and is easily converted to oxygen and water. The efficiency of this process depends on light penetration, which can be adversely affected by high turbidity and elevated nitrate concentrations $[78,86]$. There are also potential problems due to Mercury contamination from the UV lamp or the formation of toxic by-products when 
the method is combined with pre- and/or post-chlorination [78]. The lower UV absorption by $\mathrm{H}_{2} \mathrm{O}_{2}$ leads to a low generation rate for ${ }^{\circ} \mathrm{OH}$ and requires high amounts of $\mathrm{H}_{2} \mathrm{O}_{2}$ to be used, which must be removed from the wastewater after treatment.

In the Fenton process ${ }^{\circ} \mathrm{OH}$ radicals are produced from $\mathrm{H}_{2} \mathrm{O}_{2}$ through the catalytic action of ferrous ions. The main advantages associated to the classical Fenton process are the easy implementation and operation, efficiency, relatively low cost reagents, and the fact that energy is not needed for $\mathrm{H}_{2} \mathrm{O}_{2}$ activation. The electro-Fenton/bio-electro-Fenton method basically consists of electrically assisted Fenton process and has the advantages of requiring very little energy compared to other oxidation technologies that utilize $\mathrm{O}_{3}$ or UV and of not producing vapor emissions thus not requiring off-gas treatment or air permits. Within certain range of concentrations results show that Fenton oxidation was much cheaper than ozonation [87]. On the other hand it has the disadvantages of the need of an iron extraction system to remove residual iron from the treated water, which may increase the costs of the system and the need for $\mathrm{pH}$ adjustment before and after treatment. Other drawbacks are the fast consumption of $\mathrm{Fe}^{2+}$ in comparison with its regeneration rate and the complexation of some iron species and the possible waste of oxidants (e.g. due to $\mathrm{H}_{2} \mathrm{O}_{2}$ scavenging effect or self-decomposition) [88]. Nevertheless the electro-Fenton/bio-electro-Fenton process is among the most eco-friendly electrochemical AOPs and emerges as an advantageous option compared to the conventional Fenton process. The sludge produced and safety hazards associated with acids needed are disadvantages that should be mitigated by optimizing the amounts of Fenton reagents and through the implementation of safety measures. 


\section{CONCLUSIONS}

This work presents a proof-in-concept of a bio-electro-Fenton system on the basis of a MEC for the removal of low concentrations NSAIDs in municipal wastewater. The results lead to the conclusion that the system was viable for the removal of NSAIDs when in low concentration in wastewater. The apparent first order rate constant and removal efficiency varied with $\mathrm{pH}, \mathrm{FeSO}_{4}$, initial NSAIDs concentration in the catholyte, airflow rate and applied voltage in the cathode. In $5 \mathrm{~h}$, removal efficiencies were $59 \%-61 \%$ for Ketoprofen, $87 \%-97 \%$ for Diclofenac, $80 \%-86 \%$ for Ibuprofen and $75 \%-81 \%$ for Naproxen. The results obtained support this new concept as a promising and sustainable alternative for the treatment of wastewater containing low concentrations of recalcitrant micropollutants.

\section{Acknowledgements}

H. Nadais acknowledges funding from FCT - Fundação para a Ciência e Tecnologia, Portugal, through the grant SFRH/BSAB/113891/2015. This research was supported financially by The DTU PoC funding (no. 31176) and The Danish Council for Independent Research (DFF-1335-00142).

\section{REFERENCES}

[1] M. Galus, J. Jeyaranjaan, E. Smith, H. Li, C. Metcalfe, J.Y. Wilson, Chronic effects of exposure to a pharmaceutical mixture and municipal wastewater in zebrafish, $\quad$ Aquat. $\quad$ Toxicol. $132 \quad$ (2013) 212-222. doi:10.1016/j.aquatox.2012.12.016.

[2] E.J. Jasinska, G.G. Goss, P.L. Gillis, G.J. Van Der Kraak, J. Matsumoto, A.A. de Souza Machado, M. Giacomin, T.W. Moon, A. Massarsky, F. Gagné, M.R. 
Servos, J. Wilson, T. Sultana, C.D. Metcalfe, Assessment of biomarkers for contaminants of emerging concern on aquatic organisms downstream of a municipal wastewater discharge, Sci. Total Environ. 530-531 (2015) 140-153. doi:10.1016/j.scitotenv.2015.05.080.

[3] S.D. Melvin, D.R. Buck, L.D. Fabbro, Diurnal activity patterns as a sensitive behavioural outcome in fish: effect of short-term exposure to treated sewage and a sub-lethal PPCP mixture, J. Appl. Toxicol. 36 (2016) 1173-1182. doi:10.1002/jat.3284.

[4] L. Patrolecco, S. Capri, N. Ademollo, Occurrence of selected pharmaceuticals in the principal sewage treatment plants in Rome (Italy) and in the receiving surface waters, Environ. Sci. Pollut. Res. 22 (2015) 5864-5876. doi:10.1007/s11356014-3765-z.

[5] M.R. Pino, J. Val, A.M. Mainar, E. Zuriaga, C. Español, E. Langa, Acute toxicological effects on the earthworm Eisenia fetida of 18 common pharmaceuticals in artificial soil., Sci. Total Environ. 518-519 (2015) 225-37. doi:10.1016/j.scitotenv.2015.02.080.

[6] P. Falås, H.R. Andersen, A. Ledin, J. la C. Jansen, Occurrence and reduction of pharmaceuticals in the water phase at Swedish wastewater treatment plants, Water Sci. Technol. 66 (2012) 783. doi:10.2166/wst.2012.243.

[7] L.H.M.L.M. Santos, A.N. Araújo, A. Fachini, A. Pena, C. Delerue-Matos, M.C.B.S.M. Montenegro, Ecotoxicological aspects related to the presence of pharmaceuticals in the aquatic environment., J. Hazard. Mater. 175 (2010) 4595. doi:10.1016/j.jhazmat.2009.10.100.

[8] S.D. Melvin, M.C. Cameron, C.M. Lanctôt, Individual and mixture toxicity of pharmaceuticals naproxen, carbamazepine, and sulfamethoxazole to Australian 
striped marsh frog tadpoles (Limnodynastes peronii)., J. Toxicol. Environ. Health. A. 77 (2014) 337-45. doi:10.1080/15287394.2013.865107.

[9] A. Mendoza, J. Aceña, S. Pérez, M. López de Alda, D. Barceló, A. Gil, Y. Valcárcel, Pharmaceuticals and iodinated contrast media in a hospital wastewater: A case study to analyse their presence and characterise their environmental risk and hazard., Environ. Res. 140 (2015) 225-41. doi:10.1016/j.envres.2015.04.003.

[10] E. Prášková, S. Štěpánová, L. Chromcová, L. Plhalová, E. Voslářová, V. Pištěková, M. Prokeš, Z. Svobodová, The effects of subchronic exposure to ketoprofen on early developmental stages of common carp, Acta Vet. Brno. 82 (2013) 343-347. doi:10.2754/avb201382030343.

[11] J. Schwaiger, H. Ferling, U. Mallow, H. Wintermayr, R.D. Negele, Toxic effects of the non-steroidal anti-inflammatory drug diclofenac, Aquat. Toxicol. 68 (2004) 141-150. doi:10.1016/j.aquatox.2004.03.014.

[12] I. Aymerich, V. Acuña, D. Barceló, M.J. García, M. Petrovic, M. Poch, S. Rodriguez-Mozaz, I. Rodríguez-Roda, S. Sabater, D. von Schiller, L. Corominas, Attenuation of pharmaceuticals and their transformation products in a wastewater treatment plant and its receiving river ecosystem, Water Res. 100 (2016) 126136. doi:10.1016/j.watres.2016.04.022.

[13] T. Deblonde, C. Cossu-Leguille, P. Hartemann, Emerging pollutants in wastewater: A review of the literature, Int. J. Hyg. Environ. Health. 214 (2011) 442-448. doi:10.1016/j.ijheh.2011.08.002.

[14] A. Eslami, M.M. Amini, A.R. Yazdanbakhsh, N. Rastkari, A. Mohseni-Bandpei, S. Nasseri, E. Piroti, A. Asadi, Occurrence of non-steroidal anti-inflammatory drugs in Tehran source water, municipal and hospital wastewaters, and their 
ecotoxicological risk assessment, Environ. Monit. Assess. 187 (2015) 734. doi:10.1007/s10661-015-4952-1.

[15] P. Falås, A. Baillon-Dhumez, H.R. Andersen, A. Ledin, J. la Cour Jansen, Suspended biofilm carrier and activated sludge removal of acidic pharmaceuticals, Water $\quad$ Res. $46 \quad$ (2012) 1167-1175. doi:10.1016/j.watres.2011.12.003.

[16] A.E.B. Kermia, D. Fouial-Djebbar, M. Trari, Occurrence, fate and removal efficiencies of pharmaceuticals in wastewater treatment plants (WWTPs) discharging in the coastal environment of Algiers, Comptes Rendus Chim. 19 (2016) 963-970. doi:10.1016/j.crci.2016.05.005.

[17] A. Kot-Wasik, A. Jakimska, M. Śliwka-Kaszyńska, Occurrence and seasonal variations of 25 pharmaceutical residues in wastewater and drinking water treatment plants, Environ. Monit. Assess. 188 (2016) 661. doi:10.1007/s10661016-5637-0.

[18] R. Rosal, A. Rodríguez, J.A. Perdigón-Melón, A. Petre, E. García-Calvo, M.J. Gómez, A. Agüera, A.R. Fernández-Alba, Occurrence of emerging pollutants in urban wastewater and their removal through biological treatment followed by ozonation, Water Res. 44 (2010) 578-588. doi:10.1016/j.watres.2009.07.004.

[19] C.G. Daughton, T.A. Ternes, Pharmaceuticals and personal care products in the environment: agents of subtle change?, Environ. Health Perspect. 107 Suppl 6 (1999) 907-38. http://www.ncbi.nlm.nih.gov/pubmed/10592150 (accessed September 5, 2017).

[20] T.A. Ternes, M. Bonerz, N. Herrmann, B. Teiser, H.R. Andersen, Irrigation of treated wastewater in Braunschweig, Germany: An option to remove pharmaceuticals and musk fragrances, Chemosphere. 66 (2007) 894-904. 
doi:10.1016/j.chemosphere.2006.06.035.

[21] Q. Yan, X. Gao, Y.-P. Chen, X.-Y. Peng, Y.-X. Zhang, X.-M. Gan, C.-F. Zi, J.-S. Guo, Occurrence, fate and ecotoxicological assessment of pharmaceutically active compounds in wastewater and sludge from wastewater treatment plants in Chongqing, the Three Gorges Reservoir Area., Sci. Total Environ. 470-471 (2014) 618-30. doi:10.1016/j.scitotenv.2013.09.032.

[22] Z. Li, A. Sobek, M. Radke, Fate of Pharmaceuticals and Their Transformation Products in Four Small European Rivers Receiving Treated Wastewater., Environ. Sci. Technol. 50 (2016) 5614-21. doi:10.1021/acs.est.5b06327.

[23] L. Feng, E.D. van Hullebusch, M.A. Rodrigo, G. Esposito, M.A. Oturan, Removal of residual anti-inflammatory and analgesic pharmaceuticals from aqueous systems by electrochemical advanced oxidation processes. A review, Chem. Eng. J. 228 (2013) 944-964. doi:10.1016/j.cej.2013.05.061.

[24] M.A. Oturan, J.-J. Aaron, Advanced Oxidation Processes in Water/Wastewater Treatment: Principles and Applications. A Review, Crit. Rev. Environ. Sci. Technol. 44 (2014) 2577-2641. doi:10.1080/10643389.2013.829765.

[25] E. Brillas, J.C. Calpe, J. Casado, Mineralization of 2 , 4-D By Advanced Electrochemical Oxidation Processes, Water Res. 34 (2000) 2253-2262. doi:10.1016/S0043-1354(99)00396-6.

[26] E. Isarain-Chávez, C. Arias, P.L. Cabot, F. Centellas, R.M. Rodríguez, J.A. Garrido, E. Brillas, Mineralization of the drug $\beta$-blocker atenolol by electroFenton and photoelectro-Fenton using an air-diffusion cathode for $\mathrm{H} 2 \mathrm{O} 2$ electrogeneration combined with a carbon-felt cathode for Fe2+ regeneration, Appl. Catal. B Environ. 96 (2010) 361-369. doi:10.1016/j.apcatb.2010.02.033.

[27] M.A. Oturan, An ecologically effective water treatment technique using 
electrochemically generated hydroxyl radicals for in situ destruction of organic pollutants: Application to herbicide 2,4-D, J. Appl. Electrochem. 30 (2000) 475482. doi:10.1023/A:1003994428571.

[28] A. Özcan, Y. Şahin, A. Savaş Koparal, M.A. Oturan, Carbon sponge as a new cathode material for the electro-Fenton process: Comparison with carbon felt cathode and application to degradation of synthetic dye basic blue 3 in aqueous medium, J. Electroanal. Chem. $616 \quad$ (2008) 71-78. doi:10.1016/j.jelechem.2008.01.002.

[29] M.M. Ghoneim, H.S. El-Desoky, N.M. Zidan, Electro-Fenton oxidation of Sunset Yellow FCF azo-dye in aqueous solutions, Desalination. 274 (2011) 2230. doi:10.1016/j.desal.2011.01.062.

[30] Z. Ai, H. Xiao, T. Mei, J. Liu, L. Zhang, K. Deng, J. Qiu, Electro-Fenton Degradation of Rhodamine $\mathrm{B}$ Based on a Composite Cathode of $\mathrm{Cu} 2 \mathrm{O}$ Nanocubes and Carbon Nanotubes, J. Phys. Chem. C. 112 (2008) 11929-11935. doi:10.1021/jp803243t.

[31] I. Sirés, E. Brillas, Remediation of water pollution caused by pharmaceutical residues based on electrochemical separation and degradation technologies: A review, Environ. Int. 40 (2012) 212-229. doi:10.1016/j.envint.2011.07.012.

[32] X. Li, X. Jin, N. Zhao, I. Angelidaki, Y. Zhang, Novel bio-electro-Fenton technology for azo dye wastewater treatment using microbial reverseelectrodialysis electrolysis cell, Bioresour. Technol. 228 (2017) 322-329. doi:10.1016/j.biortech.2016.12.114.

[33] X. Zhu, J. Ni, Simultaneous processes of electricity generation and p-nitrophenol degradation in a microbial fuel cell, Electrochem. Commun. 11 (2009) 274-277. doi:10.1016/j.elecom.2008.11.023. 
[34] L. Fu, S.-J. You, G. Zhang, F.-L. Yang, X. Fang, Degradation of azo dyes using in-situ Fenton reaction incorporated into $\mathrm{H} 2 \mathrm{O} 2$-producing microbial fuel cell, Chem. Eng. J. 160 (2010) 164-169. doi:10.1016/j.cej.2010.03.032.

[35] L. Zhuang, S. Zhou, Y. Yuan, M. Liu, Y. Wang, A novel bioelectro-Fenton system for coupling anodic COD removal with cathodic dye degradation, 2010. doi:10.1016/j.cej.2010.07.039.

[36] R.A. Rozendal, E. Leone, J. Keller, K. Rabaey, Efficient hydrogen peroxide generation from organic matter in a bioelectrochemical system, 2009. doi:10.1016/j.elecom.2009.07.008.

[37] X. Li, X. Jin, N. Zhao, I. Angelidaki, Y. Zhang, Efficient treatment of aniline containing wastewater in bipolar membrane microbial electrolysis cell-Fenton system, Water Res. 119 (2017) 67-72. doi:10.1016/j.watres.2017.04.047.

[38] Y. Zhang, Y. Wang, I. Angelidaki, Alternate switching between microbial fuel cell and microbial electrolysis cell operation as a new method to control $\mathrm{H} 2 \mathrm{O} 2$ level in Bioelectro-Fenton system, J. Power Sources. 291 (2015) 108-116. doi:10.1016/j.jpowsour.2015.05.020.

[39] N. El-Hanafi, L. Mehibel, H.Z. Li, S. Poncin, K. Bensadok, Mineralization of the Pharmaceutical $\beta$-Blocker Atenolol by Means of Indirect Electrochemical Advanced Oxidation Process: Parametric and Kinetic Study, Sep. Sci. Technol. 49 (2014) 2942-2950. doi:10.1080/01496395.2014.943771.

[40] M.G. Antoniou, H.R. Andersen, Comparison of UVC/S2O82- with UVC/H2O2 in terms of efficiency and cost for the removal of micropollutants from groundwater, $\quad$ Chemosphere. $\quad 119 \quad$ (2015) S81-S88. doi:10.1016/j.chemosphere.2014.03.029.

[41] G. Hey, A. Ledin, J. la C. Jansen, H.R. Andersen, Removal of pharmaceuticals in 
biologically treated wastewater by chlorine dioxide or peracetic acid., Environ. Technol. 33 (2012) 1041-7. doi:10.1080/09593330.2011.606282.

[42] V.G. Samaras, N.S. Thomaidis, A.S. Stasinakis, G. Gatidou, T.D. Lekkas, Determination of selected non-steroidal anti-inflammatory drugs in wastewater by gas chromatography-mass spectrometry, Int. J. Environ. Anal. Chem. 90 (2010) 219-229. doi:10.1080/03067310903243936.

[43] F.A. Alatraktchi, Y. Zhang, J.S. Noori, I. Angelidaki, Surface area expansion of electrodes with grass-like nanostructures and gold nanoparticles to enhance electricity generation in microbial fuel cells, Bioresour. Technol. 123 (2012) 177-183. doi:10.1016/j.biortech.2012.07.048.

[44] E. Brillas, I. Sirés, M.A. Oturan, Electro-fenton process and related electrochemical technologies based on fenton's reaction chemistry, Chem. Rev. 109 (2009) 6570-6631. doi:10.1021/cr900136g.

[45] P.V. Nidheesh, R. Gandhimathi, Trends in electro-Fenton process for water and wastewater treatment: An overview, Desalination. 299 (2012) 1-15. doi:10.1016/j.desal.2012.05.011.

[46] L. Zhang, X. Yin, S.F.Y. Li, Bio-electrochemical degradation of paracetamol in a microbial fuel cell-Fenton system, Chem. Eng. J. 276 (2015) 185-192. doi:10.1016/j.cej.2015.04.065.

[47] T. Ling, B. Huang, M. Zhao, Q. Yan, W. Shen, Repeated oxidative degradation of methyl orange through bio-electro-Fenton in bioelectrochemical system (BES)., Bioresour. $\quad$ Technol. $203 \quad$ (2016) 89-95. doi:10.1016/j.biortech.2015.12.031.

[48] M. Skoumal, R.M. Rodríguez, P.L. Cabot, F. Centellas, J.A. Garrido, C. Arias, E. Brillas, Electro-Fenton, UVA photoelectro-Fenton and solar photoelectro-Fenton 
degradation of the drug ibuprofen in acid aqueous medium using platinum and boron-doped diamond anodes, Electrochim. Acta. 54 (2009) 2077-2085. doi:10.1016/j.electacta.2008.07.014.

[49] S.L. Ambuludi, M. Panizza, N. Oturan, A. Özcan, M.A. Oturan, Kinetic behavior of anti-inflammatory drug ibuprofen in aqueous medium during its degradation by electrochemical advanced oxidation, Environ. Sci. Pollut. Res. 20 (2013) 2381-2389. doi:10.1007/s11356-012-1123-6.

[50] S. Yuan, N. Gou, A.N. Alshawabkeh, A.Z. Gu, Efficient degradation of contaminants of emerging concerns by a new electro-Fenton process with Ti/MMO cathode, Chemosphere. 93 (2013) 2796-2804. doi:10.1016/j.chemosphere.2013.09.051.

[51] K. V Plakas, A.J. Karabelas, S.D. Sklari, V.T. Zaspalis, Efficient degradation of recalcitrant pharmaceuticals by a novel electro-fenton system:The case of diclofenac, $5-7$. http://www.gnest.org/proceedings/cest2013/public_html/papers/0817.pdf (accessed September 6, 2017).

[52] R.S. Rocha, A.A.G.F. Beati, J.G. Oliveira, M.R. V. Lanza, Avaliação da degradação do diclofenaco sódico utilizando $\mathrm{H} 2 \mathrm{O} 2 /$ fenton em reator eletroquímico, Quim. Nova. 32 (2009) 354-358. doi:10.1590/S010040422009000200016.

[53] S.D. Sklari, K. V. Plakas, P.N. Petsi, V.T. Zaspalis, A.J. Karabelas, Toward the Development of a Novel Electro-Fenton System for Eliminating Toxic Organic Substances from Water. Part 2. Preparation, Characterization, and Evaluation of Iron-Impregnated Carbon Felts as Cathodic Electrodes, Ind. Eng. Chem. Res. 54 (2015) 2059-2073. doi:10.1021/ie5048779. 
[54] L. Feng, N. Oturan, E.D. van Hullebusch, G. Esposito, M.A. Oturan, Degradation of anti-inflammatory drug ketoprofen by electro-oxidation: comparison of electro-Fenton and anodic oxidation processes, Environ. Sci. Pollut. Res. 21 (2014) 8406-8416. doi:10.1007/s11356-014-2774-2.

[55] L. Feng, M.J. Watts, D. Yeh, G. Esposito, E.D. van Hullebusch, The Efficacy of Ozone/BAC Treatment on Non-Steroidal Anti-Inflammatory Drug Removal from Drinking Water and Surface Water, Ozone Sci. Eng. 37 (2015) 343-356. doi:10.1080/01919512.2014.999910.

[56] N. Birjandi, H. Younesi, A.A. Ghoreyshi, M. Rahimnejad, Electricity generation through degradation of organic matters in medicinal herbs wastewater using bioelectro-Fenton system, J. Environ. Manage. $180 \quad$ (2016) 390-400. doi:10.1016/j.jenvman.2016.05.073.

[57] C.-T. Wang, J.-L. Hu, W.-L. Chou, Y.-M. Kuo, Removal of color from real dyeing wastewater by Electro-Fenton technology using a three-dimensional graphite cathode, J. Hazard. Mater. 152 (2008) 601-606. doi:10.1016/j.jhazmat.2007.07.023.

[58] M.A. Oturan, J. Pinson, J. Bizot, D. Deprez, B. Terlain, Reaction of inflammation inhibitors with chemically and electrochemically generated hydroxyl radicals, J. Electroanal. Chem. 334 (1992) 103-109. doi:10.1016/0022-0728(92)80563-J.

[59] M. Galehdar, H. Younesi, M. Hadavifar, A.A. Zinatizadeh, Optimization of a Photo-assisted Fenton Oxidation Process: A Statistical Model for MDF Effluent Treatment, CLEAN - Soil, Air, Water. 37 (2009) 629-637. doi:10.1002/clen.200900052.

[60] J. Beltran de Heredia, J. Torregrosa, J.R. Dominguez, E. Partido, Degradation of wine distillery wastewaters by the combination of aerobic biological treatment 
with chemical oxidation by Fenton's reagent, Water Sci. Technol. 51 (2005) 167-174. http://www.ncbi.nlm.nih.gov/pubmed/15771113 (accessed October 21, 2016).

[61] A. da Pozza, P. Ferrantelli, C. Merli, E. Petrucci, Oxidation efficiency in the electro-Fenton process, J. Appl. Electrochem. 35 (2005) 391-398. doi:10.1007/s10800-005-0801-1.

[62] F.L. Rosario-Ortiz, E.C. Wert, S.A. Snyder, Evaluation of UV/H2O2 treatment for the oxidation of pharmaceuticals in wastewater, Water Res. 44 (2010) 14401448. doi:10.1016/j.watres.2009.10.031.

[63] N. Xu, Y. Zhang, H. Tao, S. Zhou, Y. Zeng, Bio-electro-Fenton system for enhanced estrogens degradation, Bioresour. Technol. 138 (2013) 136-140. doi:10.1016/j.biortech.2013.03.157.

[64] H.C. Yoo, S.H. Cho, S.O. Ko, Modification of coagulation and Fenton oxidation processes for cost-effective leachate treatment., J. Environ. Sci. Health. A. Tox. Hazard. Subst. Environ. Eng. 36 (2001) 39-48. http://www.ncbi.nlm.nih.gov/pubmed/11381784 (accessed November 14, 2017).

[65] O. Ganzenko, C. Trellu, S. Papirio, N. Oturan, D. Huguenot, E.D. van Hullebusch, G. Esposito, M.A. Oturan, Bioelectro-Fenton: evaluation of a combined biological advanced oxidation treatment for pharmaceutical wastewater, Environ. Sci. Pollut. Res. (2017) 1-10. doi:10.1007/s11356-0178450-6.

[66] G. Cao, M. Sheng, W. Niu, Y. Fei, D. Li, Regeneration and reuse of iron catalyst for Fenton-like reactions, J. Hazard. Mater. 172 (2009) 1446-1449. doi:10.1016/j.jhazmat.2009.08.010.

[67] W.-S. Chen, S.-Z. Lin, Destruction of nitrotoluenes in wastewater by Electro- 
Fenton oxidation, J. Hazard. Mater. 168 (2009) 1562-1568. doi:10.1016/j.jhazmat.2009.03.048.

[68] H. Liu, C. Wang, Xiangzhong, X. Xuan, C. Jiang, H. Cui, A Novel ElectroFenton Process for Water Treatment: Reaction-controlled $\mathrm{pH}$ Adjustment and Performance Assessment, Environ. Sci. Technol. 41 (2007) 2937-2942. doi:10.1021/es0622195.

[69] G. Coria, I. Sirés, E. Brillas, J.L. Nava, Influence of the anode material on the degradation of naproxen by Fenton-based electrochemical processes, Chem. Eng. J. 304 (2016) 817-825. doi:10.1016/j.cej.2016.07.012.

[70] L. Feng, E.D. van Hullebusch, M.A. Rodrigo, G. Esposito, M.A. Oturan, Removal of residual anti-inflammatory and analgesic pharmaceuticals from aqueous systems by electrochemical advanced oxidation processes. A review, Chem. Eng. J. 228 (2013) 944-964. doi:10.1016/j.cej.2013.05.061.

[71] F.C. Moreira, S. Garcia-Segura, R.A.R. Boaventura, E. Brillas, V.J.P. Vilar, Degradation of the antibiotic trimethoprim by electrochemical advanced oxidation processes using a carbon-PTFE air-diffusion cathode and a borondoped diamond or platinum anode, Appl. Catal. B Environ. 160-161 (2014) 492505. doi:10.1016/j.apcatb.2014.05.052.

[72] D. Barceló, M. Petrovic, eds., Emerging Contaminants from Industrial and Municipal Waste, Springer Berlin Heidelberg, Berlin, Heidelberg, 2008. doi:10.1007/978-3-540-74795-6.

[73] V.S. Antonin, M.C. Santos, S. Garcia-Segura, E. Brillas, Electrochemical incineration of the antibiotic ciprofloxacin in sulfate medium and synthetic urine matrix, Water Res. 83 (2015) 31-41. doi:10.1016/j.watres.2015.05.066.

[74] A. Thiam, I. Sirés, E. Brillas, Treatment of a mixture of food color additives 
(E122, E124 and E129) in different water matrices by UVA and solar photoelectro-Fenton, Water Res. $81 \quad$ (2015) 178-187. doi:10.1016/j.watres.2015.05.057.

[75] A. Benito, A. Penadés, J.L. Lliberia, R. Gonzalez-Olmos, Degradation pathways of aniline in aqueous solutions during electro-oxidation with BDD electrodes and UV/H2O2 treatment, Chemosphere. $166 \quad$ (2017) 230-237. doi:10.1016/j.chemosphere.2016.09.105.

[76] A. Fernandes, M.J. Pacheco, L. Ciríaco, A. Lopes, Review on the electrochemical processes for the treatment of sanitary landfill leachates: Present and future, Appl. Catal. B Environ. 176-177 (2015) 183-200. doi:10.1016/j.apcatb.2015.03.052.

[77] S. Krishnan, H. Rawindran, C.M. Sinnathambi, J.W. Lim, Comparison of various advanced oxidation processes used in remediation of industrial wastewater laden with recalcitrant pollutants, IOP Conf. Ser. Mater. Sci. Eng. 206 (2017) 0-11. doi:10.1088/1757-899X/206/1/012089.

[78] S. Kommineni, J. Zoeckler, A. Stocking, S. Liang, A. Flores, M. Kavanaugh, 3.0 Advanced Oxidation Processes, Evaluation. 32 (2011) 1031-41. doi:10.1002/cite.200750374.

[79] J.L. Wagler, J.P.J. Malley, The Removal of MTBE from a Model Groundwater using UV/Peroxide Oxidation, J. New Engl. Water Work. Assoc. (1994) 236243.

[80] T.E. Agustina, H.M. Ang, V.K. Vareek, A review of synergistic effect of photocatalysis and ozonation on wastewater treatment, J. Photochem. Photobiol. C Photochem. Rev. 6 (2005) 264-273. doi:10.1016/j.jphotochemrev.2005.12.003. 
[81] M.J. Farré, M.I. Franch, S. Malato, J.A. Ayllón, J. Peral, X. Doménech, Degradation of some biorecalcitrant pesticides by homogeneous and heterogeneous photocatalytic ozonation, Chemosphere. 58 (2005) 1127-1133. doi:10.1016/j.chemosphere.2004.09.064.

[82] F.J. Beltrán, M. González, J.F. González, Industrial wastewater advanced oxidation. Part 1. UV radiation in the presence and absence of hydrogen peroxide, Water Res. 31 (1997) 2405-2414. doi:10.1016/S0043-1354(97)000778.

[83] I. Arslan, I.A. Balcioglu, T. Tuhkanen, D. Bahnemann, H 2 O 2 /UV-C and Fe 2+ /H 2 O 2 /UV-C versus TiO 2 /UV-A Treatment for Reactive Dye Wastewater, J. Environ. Eng. 126 (2000) 903-911. doi:10.1061/(ASCE)07339372(2000)126:10(903).

[84] C. Afonso-Olivares, C. Fernández-Rodríguez, R.J. Ojeda-González, Z. SosaFerrera, J.J. Santana-Rodríguez, J.M.D. Rodríguez, Estimation of kinetic parameters and UV doses necessary to remove twenty-three pharmaceuticals from pre-treated urban wastewater by UV/H2O2, J. Photochem. Photobiol. A Chem. 329 (2016) 130-138. doi:10.1016/j.jphotochem.2016.06.018.

[85] N. Gao, Y. Deng, D. Zhao, Ametryn degradation in the ultraviolet (UV) irradiation/hydrogen peroxide (H2O2) treatment, J. Hazard. Mater. 164 (2009) 640-645. doi:10.1016/j.jhazmat.2008.08.038.

[86] J. Prado, S. Esplugas, Comparison of Different AOPs involving Ozone to Eliminate Atrazine, Ozone Sci. Eng. 21 (1999) 39-52.

[87] P. Cañizares, R. Paz, C. Sáez, M.A. Rodrigo, Costs of the electrochemical oxidation of wastewaters: A comparison with ozonation and Fenton oxidation $\begin{array}{lllll}\text { processes, J. } & \text { Environ. } & \text { Manage. } 90 \quad \text { (2009) 410-420. }\end{array}$ 
doi:10.1016/j.jenvman.2007.10.010.

[88] P.V. Nidheesh, R. Gandhimathi, Trends in electro-Fenton process for water and wastewater treatment: An overview, Desalination. 299 (2012) 1-15. doi:10.1016/j.desal.2012.05.011. 


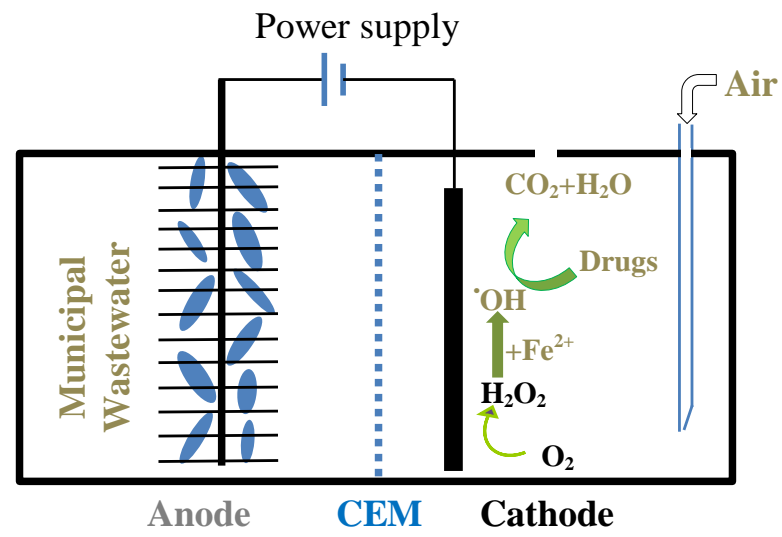

Figure 1 - Scheme of the experimental setup (CEM: cation exchange membrane) 


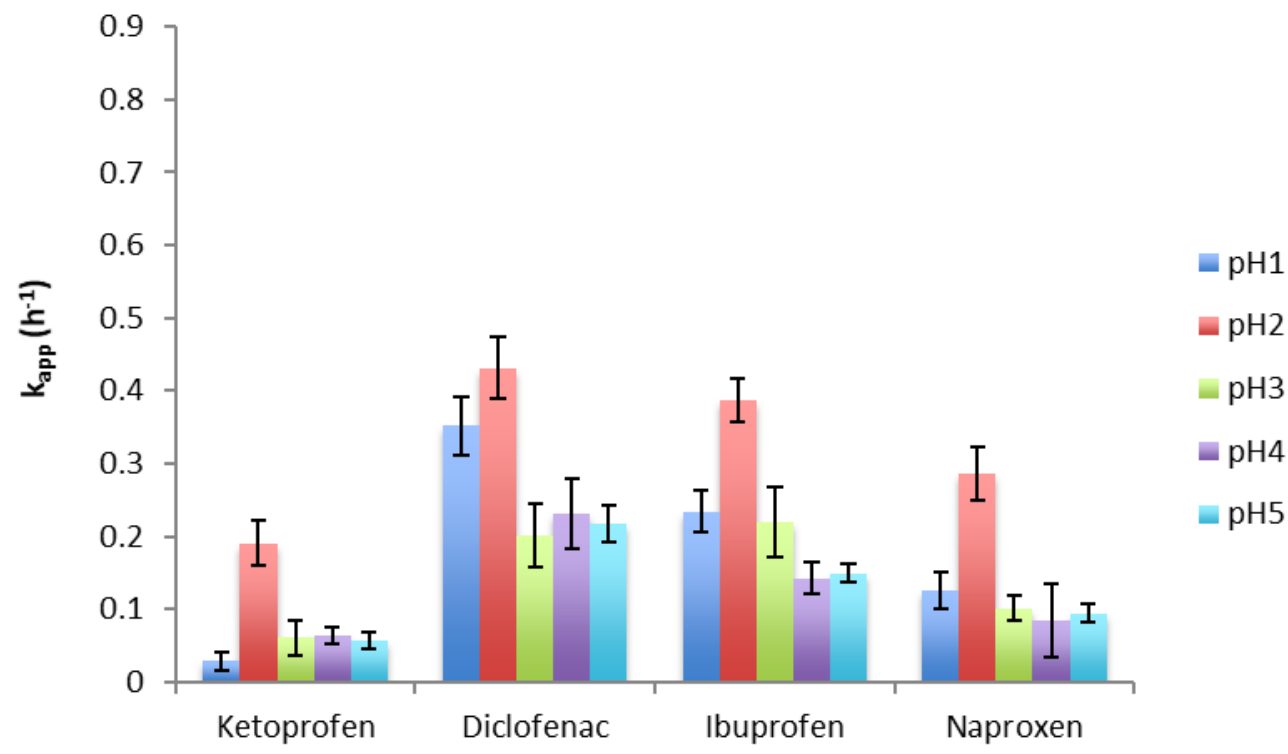

Figure 2 - Effect of catholyte $\mathrm{pH}$ on rate constant $\left(\mathrm{k}_{\text {app }}\right)$; experimental conditions: NSAIDs concentrations in catholyte $=40 \mu \mathrm{g} \mathrm{L}^{-1}$ of each compound, applied voltage $=0.5 \mathrm{~V}$, air flow $=8 \mathrm{~mL} \mathrm{~min}^{-1}, \mathrm{FeSO}_{4}$ concentration in catholyte $=5 \mathrm{mM}$, reaction time $=5$ hrs. Bars represent standard error. 


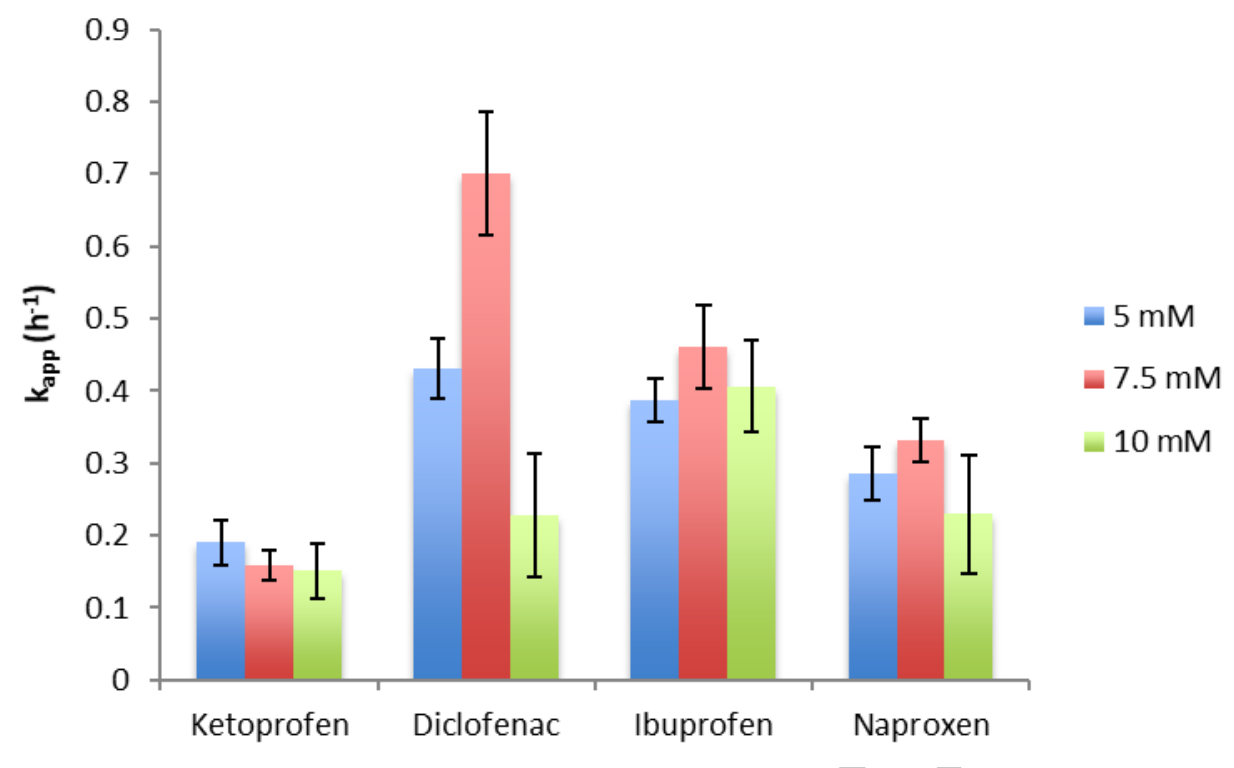

Figure 3 - Effect of $\mathrm{FeSO}_{4}$ dosage on rate constant ( $\mathrm{k}_{\text {app }}$ ); experimental conditions: NSAIDs concentrations in catholyte $=40 \mu \mathrm{g} \mathrm{L}^{-1}$ of each compound, applied voltage $=0.5 \mathrm{~V}$, air flow $=8 \mathrm{~mL} \mathrm{~min}^{-}$ ${ }^{1}$, catholyte $\mathrm{pH}=2$, reaction time $=5$ hrs. Bars represent standard error. 


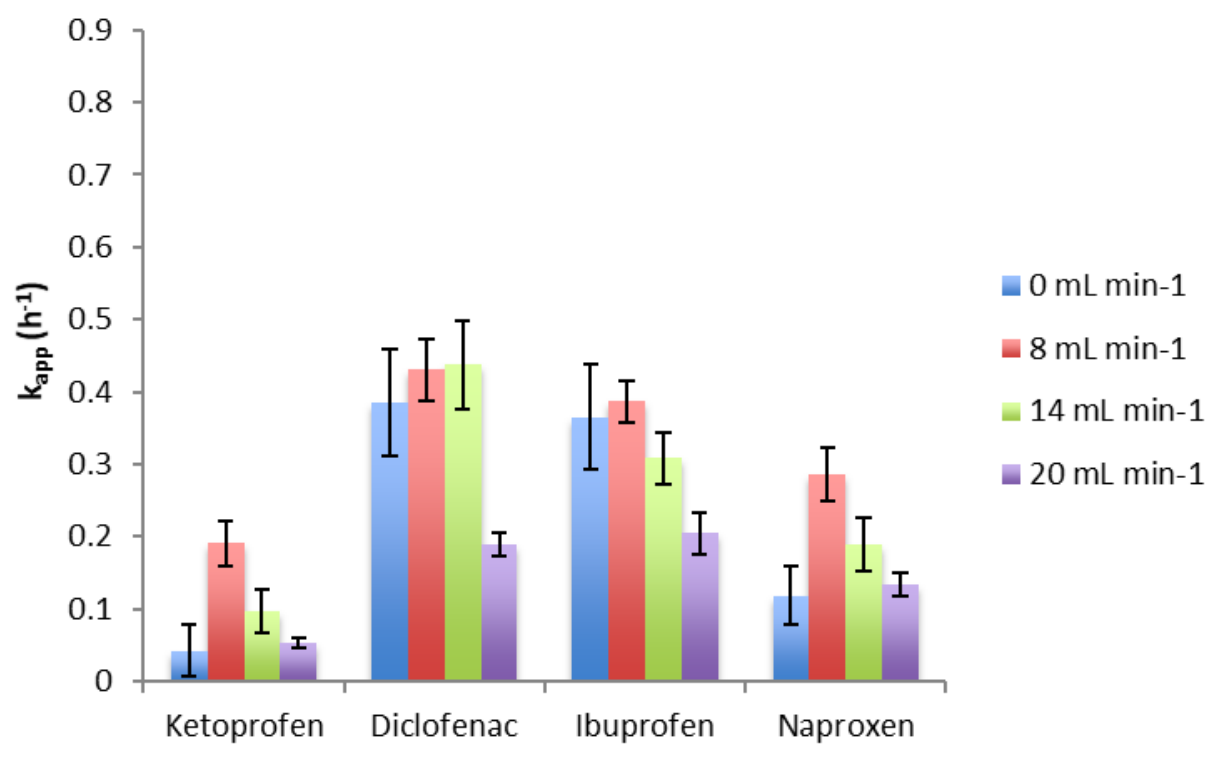

Figure 4 - Effect of airflow on rate constant $\left(\mathrm{k}_{\text {app }}\right)$; experimental conditions: NSAIDs concentrations in catholyte $=40 \mu \mathrm{g} \mathrm{L}^{-1}$ of each compound, applied voltage $=0.5 \mathrm{~V}, \mathrm{FeSO}_{4}$ concentration in catholyte $=$ $5 \mathrm{mM}$, catholyte $\mathrm{pH}=2$, reaction time $=5$ hrs. Bars represent standard error. 


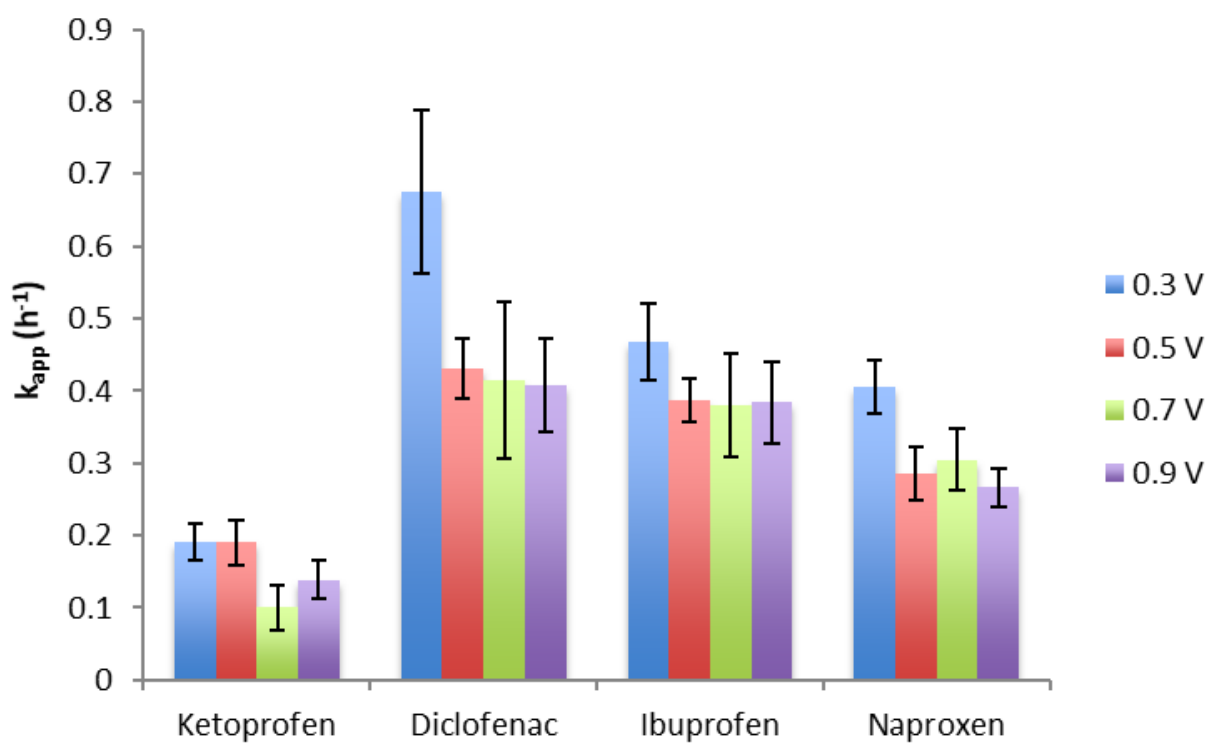

Figure 5 - Effect of applied voltage on rate constant $\left(\mathrm{k}_{\text {app }}\right)$; experimental conditions: NSAIDs concentrations in catholyte $=40 \mu \mathrm{g} \mathrm{L}^{-1}$ of each compound, air flow $=8 \mathrm{~mL} \mathrm{~min}^{-1}, \mathrm{FeSO}_{4}$ concentration in catholyte $=5 \mathrm{mM}$, catholyte $\mathrm{pH}=2$, reaction time $=5$ hrs. Bars represent standard error. 


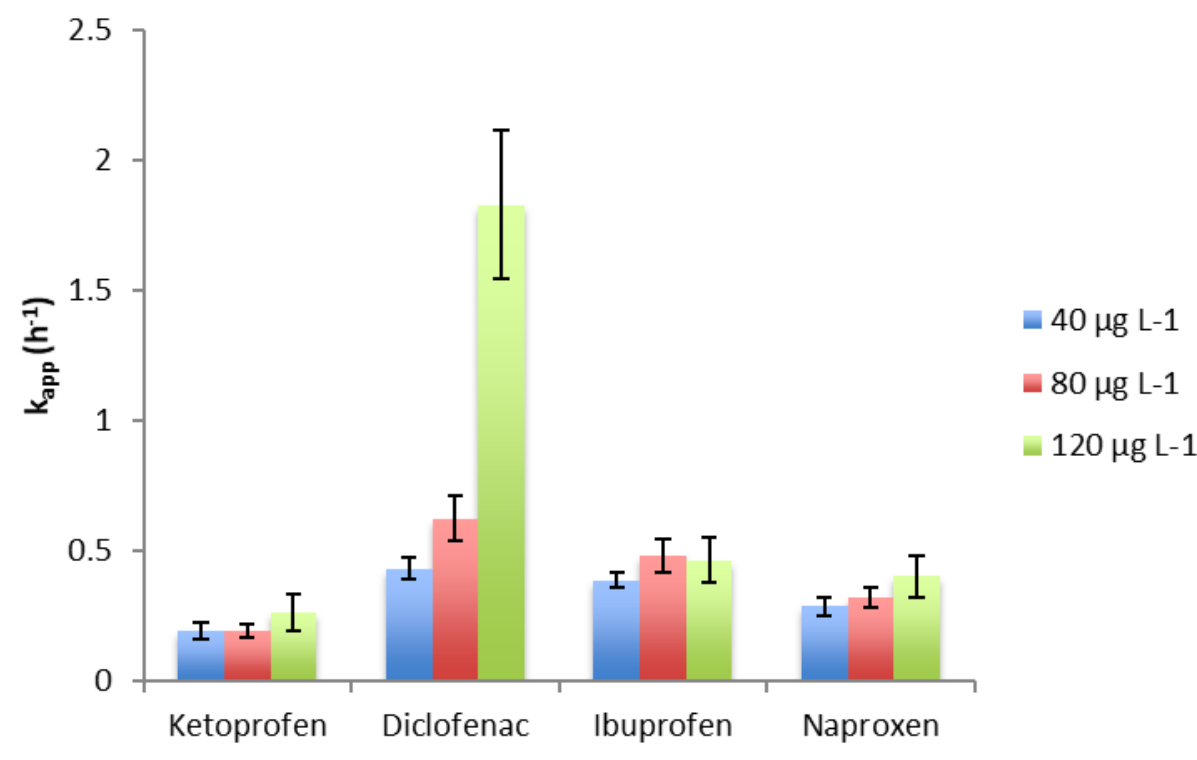

Figure 6 - Effect of substrates concentration on rate constant $\left(\mathrm{k}_{\text {app }}\right)$; experimental conditions: applied voltage $=0.5 \mathrm{~V}$, air flow $=8 \mathrm{~mL} \mathrm{~min}^{-1}, \mathrm{FeSO}_{4}$ concentration in catholyte $=5 \mathrm{mM}$, catholyte $\mathrm{pH}=2$, reaction time $=5$ hrs. Bars represent standard error. 


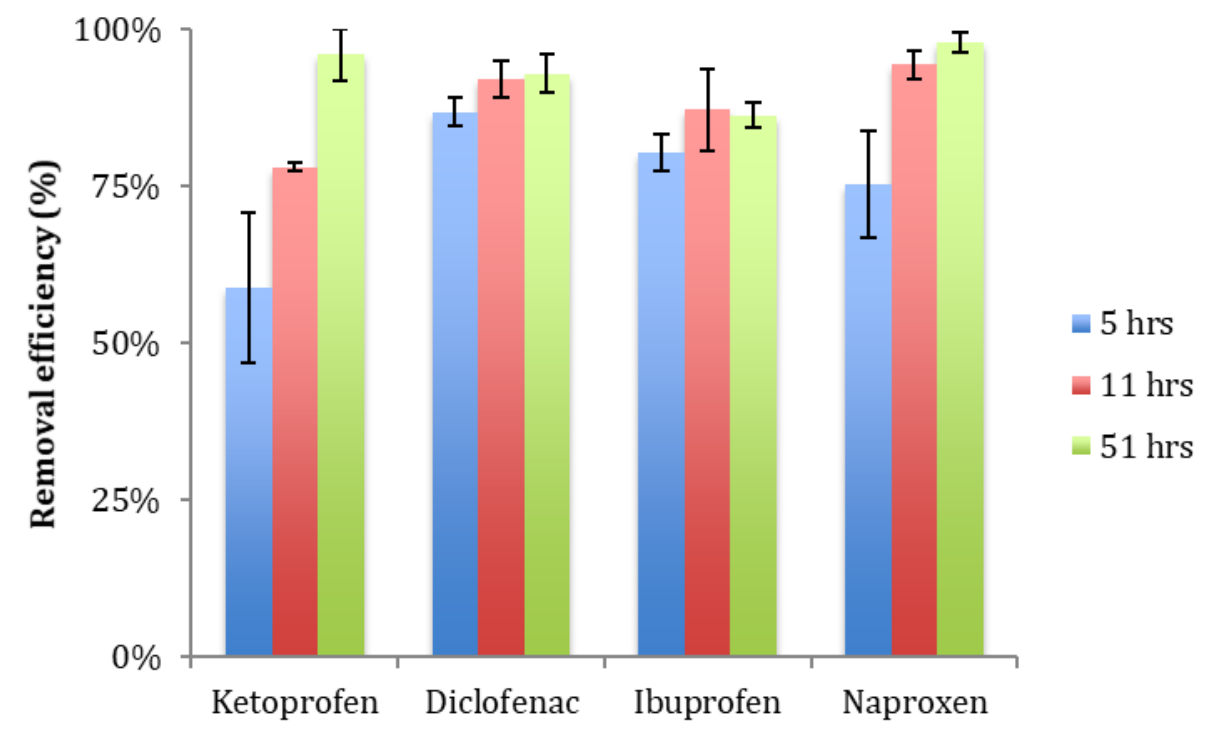

Figure 7 - Effect of reaction time on removal efficiency; experimental conditions: NSAIDs concentrations in catholyte $=40 \mu \mathrm{g} \mathrm{L}^{-1}$ of each compound; applied voltage $=0.5 \mathrm{~V}$, air flow $=8 \mathrm{~mL} \mathrm{~min}^{-}$ ${ }^{1}, \mathrm{FeSO}^{4}$ concentration in catholyte $=5 \mathrm{mM}$, catholyte $\mathrm{pH}=2$, reaction time $=5 \mathrm{hrs}$. Bars represent standard error. 


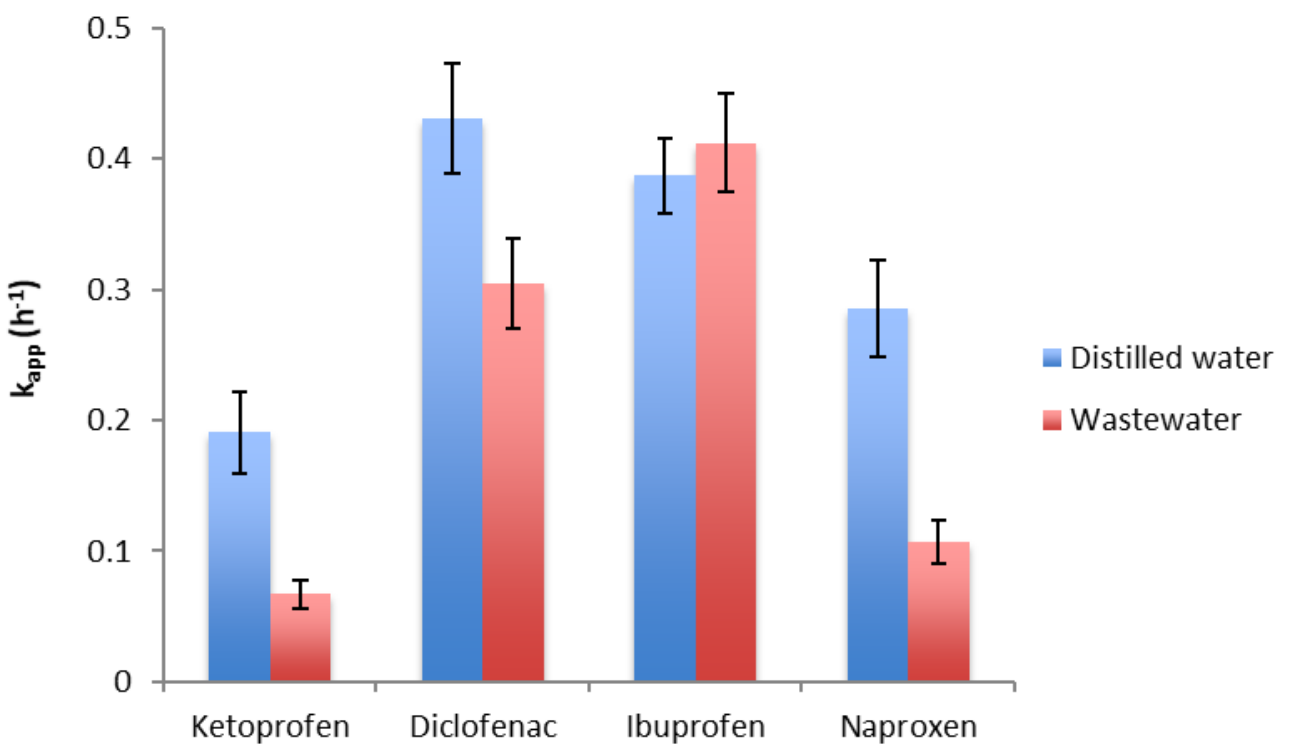

Figure 8 - Effect of sample matrix on rate constant $\left(\mathrm{k}_{\text {app }}\right)$; experimental conditions: NSAIDs concentrations in catholyte $=40 \mu \mathrm{g} \mathrm{L}^{-1}$ of each compound; applied voltage $=0.5 \mathrm{~V}$, air flow $=8 \mathrm{~mL} \mathrm{~min}^{-}$ ${ }^{1}, \mathrm{FeSO}_{4}$ concentration in catholyte $=5 \mathrm{mM}$, catholyte $\mathrm{pH}=2$, reaction time $=5$ hrs. Bars represent standard error. 
Highlights:

1) NSAIDs are ubiquitous wastewater pollutants difficult to remove in WWTP

2) Bio-Electro-Fenton process is efficient in oxidation of NSAIDs

3) BEF oxidation of NSAIDs reached $61 \%-97 \%$ in 5 hours reaction time

4) $\mathrm{Fe}^{2+}$ and NSAID concentration, $\mathrm{pH}$, air flow, voltage affect NSAIDs BEF oxidation

5) Components in real wastewater affect NSAIDs oxidation by BEF 